УДК 069; ББК 79.1; DOI https://doi.org/10.21638/11701/spbu19.2019.112

B. N. Mironov

\title{
THE COST OF EMPIRE' UNITY IN LATE IMPERIAL RUSSIA
}

Alternative perspectives concerning the significance of the Russian center in the economic development of the periphery exist in the historiography. According to one point of view, the metropole devoured the resources of the ethnic borderlands in order to secure its own prosperity and consequently hampered the periphery's development. A second view holds that the periphery prospered by absorbing the center's resources ${ }^{1}$. Similar discussions about other European empires take place in Western historiography ${ }^{2}$. Since decades, the costs and profits of the Habsburg, the French, the Spanish, the Ottoman or the Portuguese empires ${ }^{3}$ and, far

${ }^{1}$ For the historiography on this question see: Pravilova E. A. Finansy imperii: Den'gi i vlast'v politike Rossii na natsional'nykh okrainakh, 1801-1917. Moscow, 2006. P. 137-151.

${ }^{2}$ Beckert S. Empire of Cotton: A Global History. New York, 2014; Blackburn R. The Making of New World Slavery: From the Baroque to the Modern, 1492-1800. London; New York, 2010; Disparities in Economic Development since the Industrial Revolution. London, 1981; Edelstein M. Imperialism: Cost and Benefit //The Economic History of Britain since 1700. $2^{\text {nd }} \mathrm{ed}$. Cambridge, 1994. Vol. 2. P. 197-216; Imperialism and Underdevelopment: A Reader. New York, 1971; Pagden A. The Burdens of Empire: 1539 to the Present. New York, 2015; Williams E. E. Capitalism and Slavery. Kingston; Miami, 2005; Williams E. E. The Economic Aspect of the Abolition of the West Indian Slave Trade and Slavery. Lanham, 2014.

${ }^{3}$ Blinkhorn M. Spain: the 'Spanish Problem' and the Imperial Myth // Journal of Contemporary History. 1980. Vol. 15. No. 1 (January). P. 5-25; Brunschwig H. French Colonialism, 1871-1914. Myths and Realities. London, 1966; Clarence-Smith W. G. The Third Portuguese Empire, 1825-1975: A Study in Economic Imperialism. Manchester, U.K., 1985; Good D. F. The Economic Rise of the Habsburg Empire, 1750-1914. Berkeley, 1984; Hopkins A. G. The Burdens of Empire-Building // African Affairs. 1978. No. 11. P. 108-120; Matis H. Guidelines of Austrian Economic Policy, 18481918 // The Economic Development of Austria since 1870 / Ed. by H. Matis. Aldershot. England; Brookfield, Vt., USA, 1994; Pamuk Ş. A Monetary History of the Ottoman Empire. Cambridge; New York, 2004; Ránki G. On the Economic Development of the Austro-Hungarian Monarchy // Disparities in Economic Development since the Industrial Revolution / Ed. by. P. Bairoch, M. Lévy-Leboyer. London, 1981. P. 165-174; Sked A. The Decline and Fall of the Habsburg Empire, 1815-1918. London: New York, 1989; Spechler M. C. The Economic Advantages of Being Peripheral: (C) B. N. Mironov, 2019 
more developed the British empire ${ }^{4}$, are highly debated, and different authors oppose the costs and benefits of the empires, according to the sources, the period, the methods of calculation. Discourse on the cost of empire in late imperial Russia was an extremely vital matter. For example, during the work of the Special Conference on the Needs of Agricultural Industry in 1902-1905, twelve local committees of experts sharply criticized the government for the inequitable allocation of taxes, in their view, among the regions: "Central Russia bears the largest tax burden, while disbursements from state resources are carried out first and foremost in the borderlands, which is one of the chief causes of the impoverishment of the center"5. "The borderlands exhaust the center's wealth. The country is turning into a funnel. The wellbeing of its separate parts is lower, the farther they are from the periphery, the closer they are

Subordinated Nations in Multinational Empires // Eastern European Politics and Societies. 1989. Vol. 3. No. 3 (Fall). P. 448-464.

${ }^{4}$ Anderson B. L., Richardson D. Market Structures and the Profits of the British African Trade in the Late Eighteenth Century: A Rejoinder Rebutted // Journal of Economic History. 1985. Vol. 45. No. 3 (September). P. 705-707; Anstey R. T. Capitalism and Slavery: a Critique // Economic History Review. 1968. Vol. 1, No. 2 (August). P. 307-320; Anstey R. T. The Atlantic Slave Trade and British Abolition, 1760-1810. London, 1975; Davis L. E., Huttenback R. A. Mammon and the Pursuit of Empire: The Economics of British Imperialism. Cambridge; New York, 1988; Eltis D., Engerman S. The Importance of Slavery and Slave Trade to Industrializing Britain // Journal of Economic History. 2000. Vol. 60, No. 1. P. 123-144; Engerman S. E. The Slave Trade and British Capital Formation in the Eighteenth Century: A Comment on Williams Thesis // Business History Review. 1972. Vol. 46, No. 4 (Winter). P. 430-443; Hopkins A. G. Accounting for the British Empire // Journal of Imperial and Commonwealth History. 1988. Vol. 16. No. 2. P. 234-247; Inikori J. E. Africans and the Industrial Revolution in England: A Study in International Trade and Economic Development. New York, 2002; Inikori J. E. Market Structures and the Profits of the British African Trade in the Late Eighteenth Century. A Rejoinder // Journal of Economic History. 1981. Vol. 41, No.4. P. 745-776; Inikori J. E. Slavery and the Rise of Capitalism. Mona, Jamaica, 1993; Kesner R. $M$. Economic Control and Colonial Development: Crown Colony Financial Management in the Age of Joseph Chamberlain. Westport. Conn., 1981; Misra M. Lessons of Empire: Britain and India // SAIS Review: A Journal of International Affairs. 2003. Vol. XXIII. No. 2 (Summer-Fall). P. 133-153; O'Brien P., Engerman S. Exports and the Growth of the British Economy from the Glorious revolution to the Peace of Amiens // Slavery and the Rise of the Atlantic System. Cambridge: Cambridge University Press, 1991. P. 177-209; Offer A. Costs and Benefits, Peace and War // The Oxford History of the British Empire. Oxford, 1999. P. 690-711; Offer A. The British Empire 1870-1914 - a Waste of Money? // The Economic History Review. 1993. Vol. 45, No. 3. P. 215-238; Porter A. The Balance Sheet of Empire, 1850-1914// The Historical Journal. 1988. Vol. 31. No. 3 (September). P. 685-699; Richardson D. Accounting for Profits in the British Trade in Slaves: Reply to William Darity // Explorations in Economic History. 1989. Vol. 26, No. 4. P. 492-499; Richardson D. Market Structures and the Profits of the British African Trade in the Late Eighteenth Century: A Comment // Journal of Economic History. 1983. Vol. 43, No. 3 (September). P. 713-721; Richardson D. The Slave Trade, Sugar, and British Economic Growth, 1748-1776 // Explorations in Economic History. 1987. Vol. 17, No. 4. P. 739-769; Sheridan R. B. Sugar and Slavery: An Economic History of the British West Indies, 1623 1775. Kingston; Jamaica; W.I., 1994; Solow B. L. Caribbean Slavery and British Growth: The Eric Williams Hypothesis // Journal of Development Economics. 1985. Vol. 17. No. 1-2. P. 99-115.

${ }^{5}$ Trudy mestnykh komitetov o nuzhdakh sel'skokhozyaystvennoy promyshlennosti: in 58 vols. St. Petersburg, 1903. Vol. 42. Tverskaya guberniia. P. 35. 
to the center"6. The outflow of vitality and material resources to the borderlands and industrial regions creates a distinct, depressed situation in the heart of Russia, especially in the milieu of noble landownership ${ }^{7}$. In its relationship with its borderlands Russia stands in stark contrast to other countries. All states expand their possessions for quite specific purposes: either so that the territory recently being acquired can provide a new tax base and revenue for the metropole, or the territory is needed as a new market for the sale of products; but one way or another colonies and acquired territories in all states nourish the metropole and serve as a rich source of income for it. England serves as a vivid example in this respect. In Russia the situation is exactly the opposite: there is no borderland region that has not cost the country enormous sums. Even Finland costs the state no small amount of money, to say nothing of the Asian possessions ${ }^{8}$. One can compare Russia in its relation to its borderlands to a "mother, nursing her children from her own breast" . The borderlands have been placed in an especially privileged position not only with respect to the expenditure of the central government's resources upon them. Manufacturing industries develop primarily in the borderlands and the capital cities ${ }^{10}$. Any protection and assistance provided for the sale of agricultural products from the borderlands through the establishment of differentiated tariffs also entails extremely burdensome competition for the agricultural center and its outdated methods. The abundance of virgin land and the ease and low cost of production along with the advantageous tariff give the borderlands the opportunity to unload grain on the market at low prices, at a direct loss to the native oblasts of Russia ${ }^{11}$. I shall examine these points of view as hypotheses and try to verify them.

The periphery of the Russian empire really did enjoy several advantages in its development when compared with the central Great Russian regions thanks to tax exemptions, freedom from military conscription, and a favorable geographic position on the border or by the sea ${ }^{12}$. The government constantly fretted over the "cost of empire", which it understood as the expense of possessing any borderlands as part of the state. The Ministry of Finance calculated the cost as the difference between state outlays for the maintenance of its administration and armed

${ }^{6}$ Trudy mestnykh komitetov... St. Petersburg, 1903. Vol. 39. Simbirskaya guberniya. P. 521.

${ }^{7}$ Trudy mestnykh komitetov... St. Petersburg, 1903. Vol. 9. Voronezhskaya guberniya. P. 58.

${ }^{8}$ Trudy mestnykh komitetov... St. Petersburg, 1903. Vol. 45. Khar'kovskaya guberniya. P. 459.

${ }_{9}$ Trudy mestnykh komitetov... St. Petersburg, 1903. Vol. 43. Tul'skaya guberniya. P. 80.

${ }^{10}$ Trudy mestnykh komitetov... St. Petersburg, 1903. Vol. 19. Kurskaya guberniya. P. 791; 1906. Vol. 33. Pskovskaya guberniya. P. 65; 1903. Vol. 14. Kaluzhskaya guberniya. P. 80; Smolensk, 1903. Vol. 39. Smolenskaya guberniya. P. 2, 238.

${ }^{11}$ Trudy mestnykh komitetov... St. Petersburg, 1903. Vol. 41. Tamobovskaya guberniya. P. 299; Vol. 34. Riazanskaya guberniya. P. 348; Vol. 14. Kaluzhskaya guberniya. P. 75; Obshchii obzor trudov mestnykh komitetov / S. I. Shidlovskii (sost.). St. Petersburg, 1905. (Svod trudov mestnyh komitetov po 49 guberniyam Evropeyskoy Rossii / Osoboe soveshchaniye o nuzhdakh selskohozyaystvennoy promyshlennosti. [Iss. 27]). P. 208-209; Finansovaya politika i tamozhennoe pokrovitel'stvo / B. F. Brandt (comp.). St. Petersburg, 1904. P. 19-23.

${ }^{12}$ Iasnopol'skiy N. P. O geograficheskom raspredelenii gosudarstvennykh dokhodov i raskhodov v Rossii: Opyt finansovo-statisticheskogo issledovaniia: in 2 parts. Kiev, 1890-1897. P. 1, 74, 110. - See also: Miropiev M. A. O polozhenii russkikh inorodtsev. St. Petersburg, 1901. P. 503-510; Spechler M. C. The Economic Advantages of Being Peripheral: Subordinate Nations in Multinational Empires // Eastern European Politics and Societies. 1989. Vol. 3, No. 3. P. 448-464. 
forces, the construction of borders and towns, and the installation of railways, as well as other expenses from the treasury, on the one hand, and budget revenue from all taxes and income the treasury received, on the other. With this approach the situation in 1892-1895 appeared as follows (Table 1).

Table 1. Average annual government revenue and expenditures in 1892-1895 and average annual direct taxes per capita in 1886-1895 by groups of provinces in Russia, excluding Siberia, Finland, and Central Asia

\begin{tabular}{|c|c|c|c|c|c|c|c|}
\hline Group of provinces" & 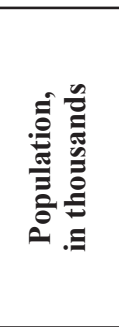 & 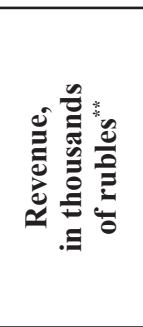 & 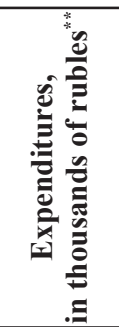 & 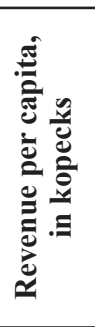 & 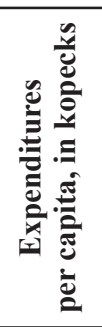 & 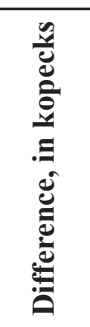 & 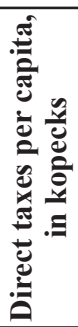 \\
\hline $\begin{array}{c}10 \text { in the Kingdom of } \\
\text { Poland }\end{array}$ & 9,443 & 99,425 & 48,069 & 10.53 & 5.09 & 5.44 & 1.35 \\
\hline 3 Baltic & 2,386 & 46,143 & 14,634 & 19.34 & 6.13 & 13.21 & 1.73 \\
\hline 6 Ukrainian & 17,221 & 130,827 & 64,611 & 7.60 & 3.75 & 3.85 & 1.27 \\
\hline Bessarabia & 1,936 & 8,919 & 5,443 & 4.61 & 2.81 & 1.80 & 1.42 \\
\hline $\begin{array}{l}\text { 7 Lithuanian- } \\
\text { Belorussian } \\
\end{array}$ & 11,676 & 50,493 & 53,187 & 4.32 & 4.56 & -0.24 & 1.14 \\
\hline 6 Caucasus & 5,995 & 40,983 & 48,442 & 6.84 & 8.08 & -1.24 & 0.79 \\
\hline 3 Pre-Caucasus & 3,729 & 13,465 & 11,616 & 3.61 & 3.12 & 0.49 & 0.53 \\
\hline 3 Black Sea & 6,282 & 72,073 & 37,654 & 11.47 & 5.99 & 5.48 & 1.49 \\
\hline $\begin{array}{l}39 \text { provinces } \\
\text { in all*** }\end{array}$ & 58,668 & 462,328 & 283,656 & 7.88 & 4.83 & 3.05 & 1.22 \\
\hline $\begin{array}{l}30 \text { Great Russian } \\
\text { provinces } * * * *\end{array}$ & 52,578 & 388,706 & 195,306 & 7.39 & 3.71 & 3.68 & 1.72 \\
\hline St. Petersburg & 2,105 & 208,520 & 394,600 & 99.06 & 187.46 & -88.4 & 7.21 \\
\hline $\begin{array}{l}31 \text { Great Russian } \\
\text { provinces in all }\end{array}$ & 54,683 & 597,226 & 589,906 & 10.92 & 10.79 & 0.13 & 1.91 \\
\hline 70 provinces in all & 113,351 & $1,059,554$ & 873,562 & 9.35 & 7.71 & 1.64 & 1.55 \\
\hline
\end{tabular}

Source: Calculated from Antropov A. P. Finansovo-statisticheskiy atlas Rossii, 1885-1895. St. Petersburg, 1898. Appendices, tables $1-4$.

* The grouping of provinces in P. A. Antropov's atlas: Polish: Warsaw, Kalish, Petrokov, Lomzha, Plotsk, Suvalki, Liublin, Kelets, Radom, Sedlets; Baltic: Kurland, Livonia, Estland; Ukrainian: Volhynia, Kiev, Podolia, Poltava, Kharkov, Chernigov; Lithuanian-Belorussian: Vilna, Vitebsk, Grodno, Kovno, Minsk, Mogilev; Caucasus: Baku, Elizavetpol, Dagestan, Kutais, Tiflis, Yerevan; Pre-Caucasus: Kuban, Stavropol, Terek; Black Sea: Ekaterinoslav, Taurida, Kherson.

** "Revenue" includes all forms of state revenue (direct and indirect taxes, redemption payments, customs duties, regalia, timber and mining income, and so forth), while "expenditures" signifies all forms of government disbursements (on administration, the army, and the like). Direct taxes include redemption payments.

*** With primarily a non-Russian population.

***** With primarily a Russian population. 
Let us ascertain which regions required more expenditures and brought greater returns to the treasury, defining public spending as expenditures on administration or as capital invested in administration, while defining state revenue as income from investments in administration or as the degree of exploitation of the regions (Table 2).

Table 2. The rating of the regions by administrative expenditures and gross profits, 1892-1895 (kopecks per capita)

\begin{tabular}{|c|c|c|c|}
\hline Group of provinces & $\begin{array}{c}\text { Treasury } \\
\text { expenditures }\end{array}$ & $\begin{array}{c}\text { Group } \\
\text { of provinces }\end{array}$ & $\begin{array}{c}\text { Treasury } \\
\text { profits }\end{array}$ \\
\hline Bessarabia & 2.81 & 3 Pre-Caucasus & 3.61 \\
\hline 3 Pre-Caucasus & 3.12 & 7 Lithuanian-Belorussian & 4.32 \\
\hline 30 Great Russian & $\mathbf{3 . 7 1}$ & Bessarabia & 4.61 \\
\hline 6 Ukrainian & 3.75 & 6 Caucasus & 6.84 \\
\hline 7 Lithuanian-Belorussian & 4.56 & 30 Great Russian & $\mathbf{7 . 3 9}$ \\
\hline 39 non-Russian provinces & $\mathbf{4 . 8 3}$ & 6 Ukrainian & 7.60 \\
\hline 10 in the Polish Kingdom & 5.09 & 39 non-Russian provinces & 7.88 \\
\hline 3 Black Sea & 5.99 & 10 in the Polish Kingdom & 10.53 \\
\hline 3 Baltic & 6.13 & 3 Black Sea & 11.47 \\
\hline 6 Caucasus & 8.08 & 3 Baltic & 19.34 \\
\hline St. Petersburg & 187.46 & St. Petersburg & 99.06 \\
\hline 70 provinces in all & 7.71 & 70 provinces in all & 9.35 \\
\hline
\end{tabular}

Source: Calculated from the data in Table 1.

Table 3. The rating of the regions by net profits on administrative expenditures, 1892-1895

\begin{tabular}{|c|c|c|c|}
\hline Group of provinces & $\begin{array}{c}\text { Net profit } \\
\text { to the treasury, in } \\
\text { kopecks per capita }\end{array}$ & Group of provinces & $\begin{array}{c}\text { Rate of return } \\
\text { for the } \\
\text { treasury, \% }\end{array}$ \\
\hline 3 Pre-Caucasus & 0.49 & St. Petersburg & -47 \\
\hline Bessarabia & 1.8 & 6 Caucasus & -15 \\
\hline 39 non-Russian provinces & 3.05 & 7 Lithuanian-Belorussian & -5 \\
\hline 30 Great Russian provinces* & $\mathbf{3 . 6 8}$ & 3 Pre-Caucasus & 16 \\
\hline 6 Ukrainian & 3.85 & 39 non-Russian provinces & $\mathbf{6 3}$ \\
\hline 10 in the Kingdom of Poland & 5.44 & Bessarabia & 64 \\
\hline 3 Black Sea & 5.48 & 3 Black Sea & 91 \\
\hline 3 Baltic & 13.21 & $\mathbf{3 0}$ Great Russian provinces & $\mathbf{9 9}$ \\
\hline 7 Lithuanian-Belorussian & -0.24 & 6 Ukrainian & 103 \\
\hline 6 Caucasian & -1.24 & 10 in the Kingdom of Poland & 107 \\
\hline St. Petersburg & -88.4 & 3 Baltic & 215 \\
\hline 70 provinces in all & 1.64 & 70 provinces in all & 21 \\
\hline
\end{tabular}

Source: Calculated from the data in Table 2.

* Excluding St. Petersburg province. 
The state invested 23 percent more in the thirty-nine non-Russian provinces than in the thirty Great Russian provinces, while it received from these provinces only 6 percent greater gross profits (state revenue) per capita. Consequently, the rate of return to the treasury on its investment in the administration of the thirty Great Russian provinces (not including St. Petersburg province, in effect the city of St. Petersburg, where numerous military units and the bureaucracy were located because of the city's status as the capital) proved to be 36 percent higher than in the thirty-nine non-Russian provinces (Table 3).

Table 4 . The balance of state revenue and expenditures by groups of provinces in 1868-1890 (millions of rubles)

\begin{tabular}{|c|c|c|c|}
\hline Group of provinces & $\mathbf{1 8 6 8}-\mathbf{1 8 7 7}$ & $\mathbf{1 8 7 8}-\mathbf{1 8 8 7}$ & $\mathbf{1 8 8 8 - 1 8 9 0}$ \\
\hline St. Petersburg & -121.272 & -197.325 & -227.230 \\
\hline Moscow & 1.227 & 18.438 & 48.078 \\
\hline Finland & -2.404 & -4.652 & - \\
\hline Northern & 4.603 & 3.923 & 4.843 \\
\hline Eastern & 13.4187 & 18.056 & 18.764 \\
\hline Central-Industrial & 22.208 & 26.148 & 35.632 \\
\hline Central-Black Earth & 47.858 & 56.474 & 70.627 \\
\hline Little Russian & 9.835 & 13.803 & 21.447 \\
\hline Baltic & 7.454 & 14.905 & 24.194 \\
\hline Northwestern & 0.668 & -1.436 & 1.667 \\
\hline Southwestern & 12.140 & 22.448 & 31.293 \\
\hline Southern & 14.414 & 21.963 & 50.890 \\
\hline Caucasus & -26.029 & -30.496 & -19.435 \\
\hline Polish & 0.540 & 6.808 & 21.224 \\
\hline Western Siberia & 1.991 & 2.815 & 0.569 \\
\hline Eastern Siberia & -2.145 & -5.940 & -5.653 \\
\hline Turkestan & -4.769 & -6.120 & -3.774 \\
\hline
\end{tabular}

Source: Calculated from Iasnopol'skii N. P. O geograficheskom raspredelenii gosudarstvennykh dokhodov i raskhodov v Rossii: Opyt finansovo-statisticheskogo issledovaniia. Prilozheniya: Statisticheskie tablitsy, kartogrammy i diagrammy. Kiev, 1897. Tables 40-41, 44-45.

* The grouping of provinces as designated by Iasnopol'skii N. P.Capital provinces (St. Petersburg, Moscow); Northern provinces (Arkhangel'sk, Vologda, Novgorod, Olonets, Pskov); Eastern provinces (Viatka, Kazan', Orenburg, Perm, Samara, Ufa); Central-industrial provinces (Vladimir, Kaluga, Kostroma, Nizhegorod, Smolensk, Tver', Iaroslavl'); Central-blackearth provinces (Voronezh, Kursk, Orel, Penza, Riazan, Saratov, Simbirsk, Tambov, Tula); Little Russian provinces (Poltava, Khar'kov, Chernigov); Baltic provinces (Kurland, Livonia, Estland); Northwestern provinces (Vilna, Vitebsk, Grodno, Kovno, Minsk, Mogilev); Southwestern provinces (Volhynia, Kiev, Podolia); Southern provinces (Astrakhan, Bessarabia, Don, Ekaterinoslav, Tavrida, Kherson); North Caucasus provinces (Stavropol'); Caucasus provinces (Baku, Tiflis); Polish provinces (Warsaw, Kalish, Petrokov, Lomzha, Plotsk, Suvalki, Liublin, Kelets, Radom, Sedlets); Western Siberian provinces (Tobol'sk, Tomsk, the Governorate General of the Steppe); Eastern Siberian provinces (Amur, Yenisei, Trans-Baikal, Irkutsk, Primorsk, Iakutsk); Turkestan. 
The data on state revenue and expenditures for 1892-1895 demonstrates that the government did not at all hamper the development of its borderlands and did not shift the burden of administrative costs to these regions. On the contrary, by means of financial mechanisms the government established preferences for the borderlands at the expense of the Great Russian provinces. These preferences diminished over time, however, which led to a reduction in the budget deficits of the non-Russian provinces and an increase in the treasury's rate of return on investment. Data for 1868-1890 provides evidence for this, according to which the deficits in the borderlands during these years were larger than in 1892-1895 (Table 4).

The situation in 1879-1881 becomes more clearly visible after converting state revenue and the treasury's expenditures into per capita terms: the Belorussian, Lithuanian, Pre-Caucasus, Caucasus, and Siberian provinces and Turkestan had deficits; the Polish provinces were practically self-sufficient and hence brought no profit to the treasury (Table 5).

Table 5. Average annual state revenue and expenditures by groups of provinces in Russia in 1879-1881 (kopecks per capita)

\begin{tabular}{|c|c|c|c|}
\hline Groups of provinces & Treasury revenue & Treasury expenditures & Rate of return, \% \\
\hline Capitals & 28.58 & 82.25 & -65 \\
\hline Northern & 4.33 & 3.27 & 32 \\
\hline Eastern & 3.92 & 2.20 & 78 \\
\hline Central-Industrial & 5.16 & 2.91 & 77 \\
\hline Central Black-Earth & 5.20 & 5.13 & 1 \\
\hline Little Russian & 4.90 & 4.04 & 21 \\
\hline Baltic & 10.85 & 3.52 & -29 \\
\hline Northwestern & 4.00 & 5.67 & 84 \\
\hline Southwestern & 6.48 & 3.52 & 15 \\
\hline Southern & 7.74 & 6.71 & -28 \\
\hline North Caucasus & 3.42 & 4.77 & -79 \\
\hline Transcaucasus & 2.39 & 11.36 & 1 \\
\hline Polish & 6.78 & 6.71 & -7 \\
\hline Siberian & 4.62 & 4.97 & -64 \\
\hline Turkestan & 1.55 & 4.36 & \\
\hline
\end{tabular}

Source: Calculated from Iasnopol'skiy N. P. O geograficheskom raspredelenii... Appendices, tables 40-41, 44-45.

Table 6 gives an even more vivid picture, demonstrating that the rate of return on state investments from 1879-1881 to 1892-1895 increased everywhere.

Considering the approximate nature of the initial information, one need not interpret the data presented here literally (that is, by what percentage returns increased). The data demonstrates a trend attributable to the policy the state pursued from the 1880 s to equalize the tax burden on the regions' population. The leveling of the tax burden is visible more graphically at the provincial level. The coefficient of variation serves as one of the best indicators of the 
differentiation ${ }^{13}$. In 1879-1881 the coefficient of variation for state income (the treasury's revenue on its expenditures on administration) in seventy provinces equaled 83 percent, while in 1892-1895 it amounted to 49 percent, that is, it decreased 1.7 times. The reduction in preferences for the regions sparked their displeasure. For example, attempts to align and equalize the contributions from Poland and Finland to the central state budget (by increasing their share of military expenditures to the level of other borderland entities) were perceived by them as a colonization policy ${ }^{14}$.

Table 6. The treasury's rate of return on "investments" in administration per capita by groups of provinces in 1879-1881 and 1892-1895 (percent)

\begin{tabular}{|c|c|c|}
\hline Provinces & $\mathbf{1 8 7 9 - 1 8 8 1}$ & $\mathbf{1 8 9 2 - 1 8 9 5}$ \\
\hline St. Petersburg & -65 & -47 \\
\hline 6 Caucasus & -79 & -15 \\
\hline 7 Lithuanian-Belorussian & -29 & -5 \\
\hline 3 Pre-Caucasus & -28 & 16 \\
\hline Finland & 1 & 30 \\
\hline 3 Black Sea & 15 & 91 \\
\hline 6 Ukrainian & 51 & 103 \\
\hline 10 Vistula Land & 1 & 107 \\
\hline 3 Baltic & 208 & 215 \\
\hline
\end{tabular}

Sources: Calculated from Antropov P. A. Finansovo-statisticheskiy atlas... Appendices, tables 1-4; Iasnopol'skiy N. P. O geograficheskom raspredelenii... Appendices, tables 40-41, 44- 45.

From 1892 to 1895, the Caucasus and the western region (the Belorussian-Lithuanian provinces), along with the steppe region of Central Asia and Turkestan, proved to be a financial drain on the empire. In the remaining "borderlands" state revenue exceeded public expenditures $^{15}$. In other years, however, regional budgets showed a surplus. Over a twenty-four-year period in the Caucasus, from 1855 to 1879 , fifteen years had a budget surplus and nine years a budget deficit. A small aggregate surplus of 6.9 million rubles over the twenty-four years and a rather low rate of return on treasury investments (5.5 percent) show that the region became self-sufficient (Table 7).

In 1883, the director of the Baku treasury chamber, A. A. Pushkarev, at the behest of the Minister of Finance Nikolai Kh. Bunge, presented "observations on all the economic and financial issues of the Transcaucasus region". According to Pushkarev, inhabitants of the Transcaucasus paid four times less when compared with the amounts paid by residents of Novgorod or Pskov province; at the same time, a muzhik from the northern provinces was obliged to pay for the Transcaucasus residents, as it were, to meet all the budget requirements of civil administration, excluding military expenditures, not covered by local revenue ${ }^{16}$. Inhabitants of Novgorod and Pskov provinces did in fact pay higher taxes, but their taxes

${ }^{13}$ The coefficient of variation is the ratio of the standard deviation to the mean.

${ }^{14}$ Pravilova E. A. Finansy imperii... P. 199, 208-239.

${ }^{15}$ Siberia also provided the treasury with a net profit: Iasnopol'skiy N. P. O geograficheskom raspredelenii...Pt. 1. P. 46.

${ }^{16}$ Quoted in: Pravilova E. A. Finansy imperii... P. 265. 
were approximately one-third greater: in 1878-1881, they paid 3.79 rubles per capita, while the Caucasus residents paid 2.78 rubles $^{17}$.

Table 7. Revenue and expenditures in the civil administration budgets of Transcaucasus krai, 1855-1880 (rubles)

\begin{tabular}{|c|c|c|c|c|c|c|c|}
\hline$\stackrel{\bar{\Xi}}{\grave{\nu}}$ & 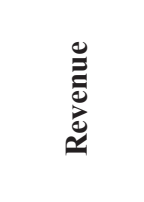 & 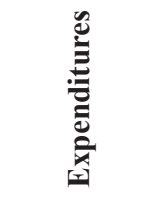 & 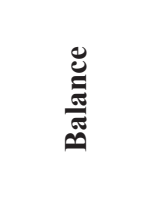 & $\stackrel{\grave{\Xi}}{\grave{J}}$ & 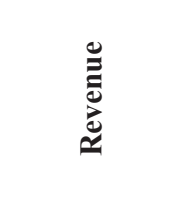 & 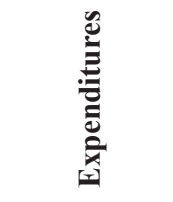 & 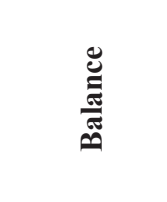 \\
\hline 1855 & $3,739,455$ & $3,640,189$ & 99,266 & 1868 & $5,228,309$ & $5,799,662$ & $-571,353$ \\
\hline 1856 & $4,816,969$ & $4,025,263$ & 791,706 & 1869 & $6,132,364$ & $6,288,281$ & $-155,917$ \\
\hline 1857 & $4,895,777$ & $3,669,785$ & $1,225,992$ & 1870 & $6,189,627$ & $6,580,196$ & $-390,569$ \\
\hline 1858 & $5,312,256$ & $4,265,105$ & $1,047,151$ & 1871 & $5,241,702$ & $6,233,374$ & $-991,672$ \\
\hline 1859 & $3,056,710$ & $2,508,218$ & 558,492 & 1872 & $5,831,533$ & $5,744,421$ & 87,112 \\
\hline 1860 & $2,993,374$ & $2,808,103$ & 185,271 & 1873 & $8,803,333$ & $6,244,879$ & $2,558,454$ \\
\hline 1861 & $3,014,068$ & $3,055,648$ & $-41,580$ & 1874 & $6,505,354$ & $6,684,829$ & $-179,475$ \\
\hline 1862 & $3,299,055$ & $3,079,141$ & $-219,914$ & 1875 & $6,539,646$ & $6,745,616$ & $-205,970$ \\
\hline 1863 & $2,595,867$ & $2,991,532$ & $-31,665$ & 1876 & $7,492,059$ & $6,622,750$ & 869,309 \\
\hline 1864 & $3,543,762$ & $3,538,239$ & 5,523 & 1877 & $7,122,199$ & $6,650,107$ & 472,092 \\
\hline 1865 & $3,883,522$ & $3,630,757$ & 252,765 & 1878 & $8,754,259$ & $7,163,364$ & $1,590,895$ \\
\hline 1866 & $4,200,967$ & $3,922,402$ & 278,574 & 1879 & $8,765,157$ & $8,632,236$ & 132,921 \\
\hline 1867 & $4,237,874$ & $4,767,770$ & $-529,896$ & Total & $132,195,198$ & $125,291,867$ & $125,291,867$ \\
\hline
\end{tabular}

Source: Esadze S. S. Istoricheskaya zapiska ob upravlenii Kavkazom: in 2 vols. Tiflis, 1907. Vol. 2. P. 306-307.

In 1883, the director of the Baku treasury chamber, A. A. Pushkarev, at the behest of the Minister of Finance Nikolai Kh. Bunge, presented "observations on all the economic and financial issues of the Transcaucasus region". According to Pushkarev, inhabitants of the Transcaucasus paid four times less when compared with the amounts paid by residents of Novgorod or Pskov province; at the same time, a muzhik from the northern provinces was obliged to pay for the Transcaucasus residents, as it were, to meet all the budget requirements of civil administration, excluding military expenditures, not covered by local revenue ${ }^{18}$. Inhabitants of Novgorod and Pskov provinces did in fact pay higher taxes, but their taxes were approximately one-third greater: in 1878-1881, they paid 3.79 rubles per capita, while the Caucasus residents paid 2.78 rubles $^{19}$.

Turkestan was included among the "unprofitable" regions up to 1908, when for the first time since 1868 the treasury received a slight profit that exceeded its expenditures by 1.6 percent. One can consider the surplus a dividend on the state's investment in Turkestan. The profit rate rose

${ }^{17}$ Iasnopol'skii N. P. O geograficheskom raspredelenii...Pt. 1. P. 236.

${ }^{18}$ Quoted in: Pravilova E. A. Finansy imperii... P. 265.

${ }^{19}$ Iasnopol'skii N. P. O geograficheskom raspredelenii...Pt. 1. P. 236. 
over four years, from 1908 to 1911, and increased to a considerable extent (to 14.8 percent), but in 1912 it declined to 7.7 percent; and from 1913 the regional budget again ran deficits (Table 8).

Table 8. State expenditures and revenue for Turkestan Krai in 1868-1916 (rubles)*

\begin{tabular}{|c|c|c|c|c|c|c|c|}
\hline 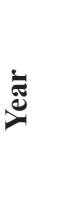 & 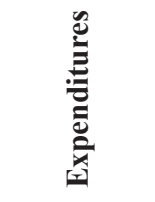 & 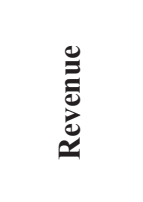 & 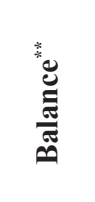 & 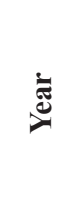 & 窇 & 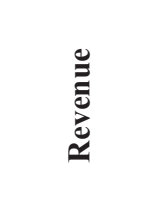 & ". \\
\hline 1868 & $3,791,795$ & - & - & 1892 & $9,085,855$ & $7,089,831$ & -22.0 \\
\hline 1869 & $4,597,971$ & $1,884,193$ & -59.0 & 1893 & $9,956,277$ & $8,053,723$ & -19.1 \\
\hline 1870 & $5,757,442$ & $1,974,430$ & -65.7 & 1894 & $9,873,573$ & $8,096,818$ & -18.0 \\
\hline 1871 & $6,366,160$ & $2,003,944$ & -68.5 & 1895 & $10,970,117$ & $7,834,481$ & -28.6 \\
\hline 1872 & $7,655,961$ & $1,940,157$ & -74.7 & 1896 & $10,606,971$ & $9,174,288$ & -13.5 \\
\hline 1873 & $8,131,229$ & $2,508,939$ & -69.1 & 1897 & $13,909,528$ & $9,894,879$ & -28.9 \\
\hline 1874 & $7,994,430$ & $2,667,650$ & -66.6 & 1898 & $12,272,367$ & $8,941,033$ & -27.1 \\
\hline 1875 & $8,739,240$ & $2,554,310$ & -70.8 & 1899 & $11,422,013$ & $7,730,622$ & -32.3 \\
\hline 1876 & $9,834,405$ & $3,623,050$ & -63.2 & 1900 & $12,916,447$ & $8,778,749$ & -32.0 \\
\hline 1877 & $9,834,453$ & $3,533,757$ & -64.1 & 1901 & $12,931,138$ & $9,302,964$ & -28.1 \\
\hline 1878 & $11,757,425$ & $3,661,654$ & -68.9 & 1902 & $20,706,765$ & $10,180,928$ & -50.8 \\
\hline 1879 & $11,434,484$ & $3,985,786$ & -65.1 & 1903 & $21,965,508$ & $11,756,168$ & -46.5 \\
\hline 1880 & $13,661,633$ & $3,988,204$ & -70.8 & 1904 & $26,267,973$ & $13,299,560$ & -49.4 \\
\hline 1881 & - & - & - & 1905 & $23,837,915$ & $13,234,511$ & -44.5 \\
\hline 1882 & - & $5,526,889$ & - & 1906 & $16,071,656$ & $15,406,947$ & -4.1 \\
\hline 1883 & - & - & - & 1907 & $16,728,371$ & $16,260,246$ & -2.8 \\
\hline 1884 & - & $6,494,090$ & - & 1908 & $16,086,622$ & $16,342,690$ & +1.6 \\
\hline 1885 & - & - & - & 1909 & $16,456,628$ & $17,588,401$ & +6.9 \\
\hline 1886 & - & $6,678,362$ & - & 1910 & $18,358,413$ & $20,105,457$ & +9.5 \\
\hline 1887 & $9,144,546$ & $6,058,978$ & -33.7 & 1911 & $18,907,297$ & $21,698,123$ & +14.8 \\
\hline 1888 & $9,773,573$ & $6,468,172$ & -33.8 & 1912 & $20,625,094$ & $22,217,285$ & +7.7 \\
\hline 1889 & $9,342,759$ & $5,984,228$ & -36.0 & 1913 & $23,162,602$ & $23,049,257$ & -0.5 \\
\hline 1890 & $8,318,827$ & $6,609,741$ & -20.5 & 1914 & - & $23,704,087$ & - \\
\hline \multirow{2}{*}{1891} & \multirow{2}{*}{$10,229,785$} & \multirow{2}{*}{$8,568,116$} & \multirow{2}{*}{-16.2} & 1915 & $38,094,184$ & - & - \\
\hline & & & & 1916 & - & $13,548,446$ & - \\
\hline
\end{tabular}

Source: Statisticheskiy ezhegodnik [Turkrespubliki], 1917-1923 gg.: in 2 vols. / D. P. Krasnovskiy (ed.). Tashkent, 1924. Vol. 2, pt. 3. P. 380.

*The years with a surplus appear in boldface.

** As a percentage of the amount of expenditures. A "minus" sign signifies a deficit, and a "plus" sign a surplus. 
The treasury began to receive a net gain from the region only in the fortieth year after the annexation of Turkestan, after spending 194 million rubles, almost 5 million rubles per year without hope of a return for thirty-nine years ${ }^{20}$. If one compares this data with the amount of land, the land area, and its value in other borderlands of the empire, "Turkestan gives the treasury four times less than other parts of the State, relatively speaking", according to the Chief Director of Land Management and Agriculture in 1912, Aleksandr V. Krivoshein ${ }^{21}$.

Nikolai P. Iasnopol'skii, in his landmark three-volume work on data from 1868-1890 convincingly demonstrated the existence of an unequal tax burden for various regions of Russia to the benefit of the borderlands: "It is mainly the interior of the territory of European Russia that finds itself more heavily taxed through all the state levies, when compared to its economic resources, than almost all the regions external to it and the capital provinces" 22 . P. A. Antropov, another leading scholar of provincial state budgets, also reached a similar conclusion $^{23}$.

The Grand Duchy of Finland had its own autonomous budget. It contributed to imperial military outlays by agreement with the Russian government and maintained the administration of the Governor-General of Finland. Its regular state revenue always exceeded expenditures, however. Nevertheless, it always carried state debt of less than the sum of two years of state revenue (Table 9$)^{24}$.

Table 9. State revenue and expenditures of the Grand Duchy of Finland and its public debt in 1877-1921 (Finnish markka per capita)

\begin{tabular}{|c|c|c|c|c|c|}
\hline & $\mathbf{1 8 7 7 - 1 8 9 0}$ & $\mathbf{1 8 9 1 - 1 9 0 4}$ & $\mathbf{1 9 0 5 - 1 9 1 3}$ & $\mathbf{1 9 1 4 - 1 9 1 7}$ & $\mathbf{1 9 1 8 - 1 9 2 1}$ \\
\hline Population, in thousands & 2151.6 & 2589.2 & 3027.6 & 3280.8 & 3343.2 \\
\hline State revenue & 19.13 & 30.40 & 51.35 & 82.35 & 429.43 \\
\hline State expenditures & 18.10 & 25.18 & 40.85 & 65.69 & 369.20 \\
\hline Government debt & 31.92 & 38.44 & 52.90 & 60.22 & 489.44 \\
\hline Military expenditures* & 15.2 & 9.4 & 4.6 & 8.0 & 17.7 \\
\hline $\begin{array}{c}\text { State debt as a percentage } \\
\text { of annual revenue }\end{array}$ & 167 & 126 & 103 & 73 & 114 \\
\hline
\end{tabular}

Source: Calculated from Annuaire statistique pour la Finlande [1877-1921]. Helsingfors, 1878-1922.

*Military expenditures as a percentage of regular state expenditures.

${ }^{20}$ Because there are gaps in the data for seven years, I calculated the average losses for the existing data covering thirty-two years (4.97 million rubles), then multiplied that amount by the total number of years (39) and obtained as a result total losses equaling 193.8 million rubles.

${ }^{21}$ Zapiska Glavnoupravlyayushchego zemleustrojstvom i zemledeliem o poezdke v Turkestanskiy kraj v 1912 godu [po voprosu rasshireniya hlopkovodstva]. Prilozhenie k vsepoddanneishemu dokladu. Poltava, 1912. P. 70.

${ }^{22}$ Iasnopol'skiy N. P. O geograficheskom raspredelenii... Pt. 1. P. 167; Pt. 2. P. 100, 563-584. This research received a positive assessment from a colleague: Pikhno D. I. Razbor sochineniya N. P. Iasnopol'skogo "O geograficheskom raspredelenii gosudarstvennykh dokhodov i raskhodov Rossii”, predstavlennogo v Yuridicheskii fakul'tet dlya priobreteniya stepeni doktora politicheskoy ekonomi i istatistiki. Kiev, 1898. P. 1-22.

${ }^{23}$ Antropov P. A. Finansovo-statisticheskiy atlas Rossii, 1885-1895. St. Petersburg, 1898. P. 5-6, tabl. 4.

${ }^{24}$ In different sources information about the budget differs. In the table for 1877-1914 the data from Annuaire statistique pour la Finlande... is for the corresponding years. 
The per-capita contributions of the duchy toward the empire's military expenses were always lower than those from the rest of the empire. In 1896, military expenditures in Russia, excluding Finland, constituted 27.4 percent of all regular state spending, but in Finland they were 16.1 percent; in 1907 these outlays were 21.4 percent and 0.2 percent, respectively; in 1910, 23.2 and 8.2 percent respectively; and in 1913, 25.8 and 8.9 percent. On average during the years 1896-1913, the percentages were 25 and $6^{25}$.

State expenditures, that is, investments in the thirty-nine non-Russian provinces, were greater than in the Great Russian provinces -4.83 rubles versus 3.71 rubles. This ensured an additional financial flow (funds designated for payment for services and for the procurement of locally produced goods for the army stationed there) from the center to the provinces settled by non-Russian populations and gave the center the opportunity to avail itself of these resources to satisfy its own needs. Regional budget shortfalls in the Belorussian-Lithuanian and Caucasus regions resulted from their position on the empire's border. The central government expended significant sums on the army, which stimulated the economic development of these regions. The deficit in St. Petersburg province stemmed from the large outlays on the central administration, the court, the army, and the Guard.

The approach of the Ministry of Finance concerning state finances and the budget makes a great deal of sense. Measuring the true "cost of empire" requires a more sophisticated and complex calculation, however. First, the methodology used by the Ministry of Finance combined all the military expenses the state incurred in a province (region [raion]) in their entirety together with its outlays in this province (or region). Consequently, the frontier provinces found themselves overburdened with military expenditures not by virtue of their annexation and the need to maintain an additional military contingent there to keep order, but strictly because of their location on the border. When a Russian province was located on the border, it had to host large military forces and bear the costs of maintaining them, as was observed, for example, in St. Petersburg province (for which reason the province was considered unprofitable and the beneficiary of state subsidies). It is inaccurate to charge all military outlays for annexed provinces on the border, in their entirety, at any rate, to the account of these provinces. As Governor-General of Turkestan Aleksandr B. Brevskii rightly pointed out in his report to the tsar in 1898, expenditures on the armed forces stemmed from national, not local, exigencies, since this krai was a border region. Had Turkestan not become part of the empire, the state would have had to maintain troops in Siberia and Orenburg krai, as had been the case earlier. Inasmuch as at that time Turkestan already made possible a reduction of up to forty million rubles in payments just for cotton despite the lack of convenient transportation routes (thereby promoting the strengthening of the ruble), additional payments to support the military cannot be considered as deficit spending in the state economy ${ }^{26}$. And if one excludes military expenditures, then no border region in the post-reform era was unprofitable. Even

${ }^{25}$ Statisticheskii ezhegodnik Rossii. 1914 g. Petrograd, 1915. Section [Otd.] 1:58; section [Otd.] 12: P. 14-15, 18-19, 22-25; Ezhegodnik Ministerstva finansov. Vypusk 1898 goda. St. Petersburg, 1899. P. 36-37, 44-45; Ezhegodnik Ministerstva finansov. Vypusk 1909 goda. St. Petersburg, 1909. P. 4-5, 52-53, 61; Ezhegodnik Ministerstva finansov. Vypusk 1912 goda. St. Petersburg, 1912. P. 4-5, 56-57, 61, 65-66.

${ }^{26}$ Rossiiskiy gosudarstvennyi istoricheskiy arkhiv (RGIA). F. 1282 (Kantseliariya ministra vnutrennikh del). Op. 3. D. 239. L. 1-28. Vsepoddanneishii otchet turkestanskogo general-gubernatora general-leitenanta barona A. B. Vrevskogo za 1895-1897 gg. (18 February 1898). 
Turkestan, excluding the disbursements for the Ministry of War, began to show a profit as early as the years 1868-1874: in these years Turkestan furnished the treasury with 6.5 percent of the returns on the total state budget outlays ${ }^{27}$. Spending on railway construction as well as on maintaining the army in border regions also should not be attributed entirely to the latter, since this spending benefited not only the incorporated krai but also the Russian territory and, ultimately, the center and the whole empire. For example, in Turkestan, in Vrevskii's view, precisely because of the growing state spending on railway construction a substantial increase in cotton exports occurred, as well as an upsurge in the incomes of the local population ${ }^{28}$.

Finally, in calculating the "cost of empire" one must take into account not only state but also private spending and revenue (that of individuals and non-governmental corporations and organizations). In this case one should take into account the net profits of trade, manufacturing, transport, and financial enterprises, for this income doubtlessly existed - otherwise they all would have become bankrupt - as well as the net proceeds immigrants and the indigenous population obtained through the krai's development under Russian influence and aid. In addition, it is necessary to consider the multiplier or cumulative effects of investment in the development of the Central Asian economy, especially in cotton cultivation, because besides the direct, primary effect in terms of national revenue and employment, investments generate indirect or tangential secondary, tertiary, and subsequent effects. Unfortunately, such calculations are never made. In this instance it is evident: the "cost of empire" was lower and the preponderance of revenue over expenditures began significantly earlier than was apparent exclusively from the flow of public funds. Moreover, both the indigenous population and colonists received the benefits of economic growth ${ }^{29}$.

The Grand Duchy of Finland presents a convincing example of obtaining economic benefits from affiliating with Russia. The century spent as a part of Russia was a period of prosperity for the Finns. Between 1809 and 1917 the population increased 3.5 times (from 863 thousand to 3 million). At the time of the duchy's declaration of its independence, only about six thousand Russians lived there continuously ( 0.2 percent of the country's population), while Swedes constituted 12.9 percent. Great strides were made in the economy, culture, art, literature, and education. The Finnish economy's growth rate surpassed the average Russian and European rates. The average annual per-capita growth rate of GDP in 1870-1913 (years for which comparable data exist) increased 0.79 percent more rapidly than in the empire as a whole and 0.02 percent faster than in all of Europe (Table 10).

In Finland the preconditions for rapid economic development had emerged, thanks in part to the large share of expenditures that could go toward public services and popular education, compared with the empire as a whole, and the much lesser proportion spent on military needs and debt repayment ${ }^{30}$. The Russian market played a significant role in Finland's economic

${ }^{27}$ Statisticheskiy ezhegodnik [Turkrespubliki], 1917-1923 gg.: in 2 vols. / D. P. Krasnovskiy (ed.). Tashkent, 1924. Vol. 2, pt. 3. P. 143-145.

${ }^{28}$ RGIA. F. 1282. Op. 3. D. 239. L. 1-28 Vsepoddanneishii otchet turkestanskogo generalgubernatora general-leitenanta barona A. B. Vrevskogo za 1895-1897 gg. (18 February 1898).

${ }^{29}$ The question of the value of Turkestan cotton to the Russian economy is a vexed one: Penati $B$. The Cotton Boom and the Land Tax in Russian Turkestan (1880s-1915) // Kritika. 2013. Vol. 14, No. 4. P. 741-774.

${ }^{30}$ Voenno-statisticheskii sbornik / N. N. Obruchev (red.). Iss. 4. Rossiya. St. Peterburg: Voennaya tipografiya, 1871. P. 820. 
development: its share of the duchy's trade volume in various years equaled from 30 to 50 percent. The economic expansion in Finland continued up to the beginning of the First World War ${ }^{31}$. Now, as to the matter of the alleged exploitation of the borderlands by the "metropole" and the depletion of their resources: In the early twentieth century the Commission to Investigate the Question of the Dynamics of the Rural Population's Welfare in the Central Agricultural Provinces from 1861 to 1901 Compared with Other Localities in European Russia (hereafter, the Commission of the Center) was active, having been established on November 16, 1901, at the initiative of Finance Minister Sergei Iu. Witte.

Table 10. Gross domestic product (GDP) per capita in Europe and the United States of America (1990 international dollars*)

\begin{tabular}{|c|c|c|c|c|c|c|c|}
\hline & \multicolumn{4}{|c|}{ GDP per capita } & \multicolumn{3}{c|}{ Growth rates of GDP per capita } \\
\cline { 2 - 8 } & 1870 & 1913 & 1937 & 1950 & $1870-1913$ & $1913-1937$ & $1913-1950$ \\
\hline The Russian Empire & 1097 & 1551 & 2267 & 2827 & 0.934 & 1.016 & 1.019 \\
\hline Finland & 1290 & 2288 & 3638 & 4362 & 1.013 & 1.020 & 1.011 \\
\hline Poland & - & 1739 & 1915 & 2447 & - & 1.004 & 1.009 \\
\hline Denmark & 1929 & 3768 & 5601 & 6404 & 1.016 & 1.017 & 1.008 \\
\hline Norway & 1370 & 2454 & 4180 & 5376 & 1.014 & 1.022 & 1.012 \\
\hline Sweden & 1247 & 2806 & 4565 & 6539 & 1.019 & 1.022 & 1.014 \\
\hline $\begin{array}{c}\text { Central and Eastern } \\
\text { Europe }\end{array}$ & 1437 & 2250 & 2720 & 3016 & 1.010 & 1.008 & 1.008 \\
\hline Europe & 1686 & 2643 & 3217 & 3579 & 1.011 & 1.008 & 1.008 \\
\hline USA & 2445 & 5301 & 6430 & 9561 & 1.018 & 1.008 & 1.009 \\
\hline
\end{tabular}

Sources: Calculated from Maddison A. World Population, GDP and Per Capita GDP, 1-2008 AD (Groningen Growth and Development Centre).Access Modehttp://www.ggdc.net/MADDISON/oriindex.htm (last visited - May 2019); Broadberry S. Aggregate and Per Capita GDP in Europe, 1870-2000: Continental, Regional and National Data with Changing Boundaries.Access Modehttps://www.nuffield.ox.ac.uk/users/ Broadberry/EuroGDP2.pdf (27 October 2011; File: EuroGDP2) (last visited - July 2017).

* 1990 International Geary-Khamis dollars.

The commission's task was defined as follows: the collection of statistical materials describing comprehensively the development of agriculture after the abolition of serfdom in the fifty provinces of European Russia over a period of forty years, from 1861 to 1900. More than one hundred specialists participated in the research effort. Working through the Department of Direct Taxes of the Ministry of Finance over the course of two years, experts collected, processed, and in October 1903 printed the most complete digest of largely unpublished information from departmental and, to some extent, zemstvo statistics. The first part of the work included data on the state of the peasant economy in each of the fifty provinces from 1861 to

${ }^{31}$ Beloglazov $A$. $V$. Federalizm v «tiur'me narodov»: Velikoe kniazhestvo Finliandskoe // Federalizm: problemy formirovaniia: Materialy postoianno deistvuiushchego seminara. Kazan', 1994. P. 41-47; Bobovich I. M. Russko-finlyandskiye ekonomicheskiye otnosheniya nakanune Velikoy Oktyabr'skoy sotsialisticheskoy revoliutsii: (Epokha imperializma). Leningrad, 1968; Kornilov G. D. Russko-finlyandskiye tamozhennye otnosheniya v kontse XIX - nachale XX v. Leningrad, 1971; Nacional'naya politika v imperatorskoy Rossii: in 2 vols. T. 1: Civilizovannye okrainy (Finliandiya, Pol'sha, Pribaltika, Bessarabiya, Ukraina, Zakavkazye, Srednyaya Aziya). Moscow, 1997; Rasila V. Istoriia Finliandii. Petrozavodsk, 1996. 
1900, grouped into twelve regions by twenty-six characteristics: population (population size, marriage rate, birth rate, death rate, natural increase), migration, military conscription and marriages to soldiers, budgets, vodka consumption, the trends of savings bank deposits, land under cultivation, the size of land allotments, the degree of correspondence of land allotments to the workforce and food needs, trends in land ownership through buying and selling, land purchases with the aid of the Peasant Land Bank, rents, sowing and harvesting of grains, grain prices, yields of allotment land according to zemstvo statistical surveys, number of livestock, earnings from local and seasonal work, quantity of passport forms sold for the right to leave for seasonal work, earnings from local landowners, wages for agricultural workers, surpluses or deficits of local laborers, the collection of direct taxes and the proportional stamp duties, and trends in deposits in the State Nobles' Land Bank.

Not only did the Commission of the Center collect unique materials, but it applied an interesting and original methodology to its processing of the data - evidence that professional statisticians worked as members of the Commission's staff. The Commission set a dual goal: to estimate the average welfare level in 1900 and the average rate of changes in this level during the years 1861-1900. To this end, for the year 1900 all fifty provinces received a rank or rating from 1 to 50 for each of twenty-four factors; hence, each province had twenty-four ratings. Then each factor was assigned a weight from 1 to 4 corresponding to its contribution to peasant welfare. An average composite rating for each province was calculated based on the rating and weight of each factor cumulatively for all twenty-four factors - the aggregate welfare level index of the province. This was computed in two ways: the first included the twenty-four factors, the second - twenty (for ten of them the weighting was changed). In the first version, the aggregate index varied from 15.26 for Orel province to 34.63 for the Don oblast, and in the second version, from 13.93 in Orel to 34.71 in Tavrida (the Don oblast placed third with an index of 32.52). As is evident, both calculation variants produced approximately equivalent results.

The Commission achieved its second goal in similar fashion. The average rate of change was calculated for the fifty provinces for all twenty-four factors through the years 1861-1900, in accordance with which a province received a rating (from 1 to 50). Based on the twentyfour ratings the statisticians determined the aggregate index of the welfare dynamics for each province. The Commission assigned a weight from 1 to 4 to each factor of the dynamics according to its contribution to peasant welfare. On the basis of the rating and weight of each factor they calculated the average composite rating of all twenty-four factors cumulatively the aggregate index of the welfare dynamics of a province. The results of the analysis are presented in Table 11.

The data presented here show that with respect to the level of economic development in 1900 and the rates of development in the post-reform period there are practically no differences among the 28 provinces in which the population share of Russians exceeded 50 percent (Great Russian provinces) and the 22 provinces in which the Russian share was less than 50 percent (the nonRussian provinces), since the average composite ranks differed extremely little -24.9 versus 26.2 for level of development and 25.2 versus 25.9 for growth rates. Strictly speaking, a very minute advantage existed for the non-Russian provinces. If one divides and classifies the provinces by the numerically predominant ethnicity, the Great Russian provinces are located approximately in the middle (Table 12). 
Table 11. Rating of the 50 provinces of European Russia by their welfare level in 1901 and by the growth rate in 1861-1900

\begin{tabular}{|c|c|c|c|c|c|c|c|}
\hline \multirow[b]{2}{*}{ Province } & \multirow[b]{2}{*}{$\begin{array}{c}\% \\
\text { Russian }\end{array}$} & \multicolumn{2}{|c|}{ Rating by } & \multirow[b]{2}{*}{ Province } & \multirow[b]{2}{*}{$\begin{array}{c}\% \\
\text { Russian }\end{array}$} & \multicolumn{2}{|c|}{ Rating by } \\
\hline & & $\begin{array}{l}\text { level of } \\
\text { develop- } \\
\text { ment }\end{array}$ & $\begin{array}{l}\text { develop- } \\
\text { mental } \\
\text { growth } \\
\text { rate }\end{array}$ & & & $\begin{array}{l}\text { level of } \\
\text { develop- } \\
\text { ment }\end{array}$ & $\begin{array}{c}\text { develop- } \\
\text { mental } \\
\text { growth } \\
\text { rate }\end{array}$ \\
\hline Archangel'sk & 85 & 23 & 30 & Novgorod & 97 & 22 & 33 \\
\hline Astrakhan & 41 & 31 & 20 & Olonets & 78 & 22 & 25 \\
\hline Bessarabia & 8 & 29 & 23 & Orenburg & 70 & 32 & 35 \\
\hline Vilna & 5 & 26 & 31 & Orel & 99 & 24 & 27 \\
\hline Vitebsk & 13 & 26 & 31 & Penza & 83 & 29 & 22 \\
\hline Vladimir & 100 & 27 & 29 & Perm & 90 & 15 & 20 \\
\hline Vologda & 91 & 25 & 23 & Podolia & 3 & 18 & 21 \\
\hline Volhynia & 4 & 24 & 32 & Poltava & 3 & 28 & 24 \\
\hline Voronezh & 63 & 19 & 16 & Pskov & 95 & 20 & 27 \\
\hline Viatka & 77 & 28 & 25 & Riazan & 99 & 22 & 22 \\
\hline Grodno & 5 & 26 & 24 & Samara & 65 & 28 & 25 \\
\hline Don & 67 & 35 & 26 & St. Petersburg & 82 & 17 & 18 \\
\hline Ekaterinoslav & 17 & 33 & 25 & Saratov & 81 & 28 & 16 \\
\hline Kazan’ & 38 & 20 & 22 & Simbirsk & 68 & 31 & 34 \\
\hline Kaluga & 99 & 22 & 28 & Smolensk & 92 & 26 & 22 \\
\hline Kiev & 6 & 22 & 25 & Tavrida & 28 & 19 & 21 \\
\hline Kovno & 5 & 22 & 29 & Tambov & 95 & 32 & 35 \\
\hline Kostroma & 100 & 32 & 30 & Tver' & 93 & 34 & 22 \\
\hline Kurland & 4 & 25 & 23 & Tula & 100 & 20 & 20 \\
\hline Kursk & 77 & 16 & 18 & Ufa & 38 & 29 & 33 \\
\hline Livonia & 5 & 29 & 24 & Khar'kov & 18 & 16 & 22 \\
\hline Minsk & 4 & 31 & 32 & Kherson & 21 & 29 & 24 \\
\hline Mogilev & 3 & 27 & 30 & Chernigov & 22 & 20 & 21 \\
\hline Moscow & 98 & 22 & 33 & Estland & 5 & 29 & 23 \\
\hline Nizhegorod & 93 & 22 & 25 & Iaroslavl' & 99 & 21 & 25 \\
\hline \multicolumn{5}{|c|}{ Average in 28 provinces populated mainly by Russians } & 86 & 24.9 & 25.2 \\
\hline \multicolumn{5}{|c|}{ Average in 22 provinces populated mainly by non-Russians } & 13 & 26.2 & 25.9 \\
\hline \multicolumn{5}{|c|}{ Average in all 50 provinces } & 52 & 25.5 & 25.5 \\
\hline
\end{tabular}

Source: Materialy vysochayshe uchrezhdennoy 16 noyabrya $1901 \mathrm{~g}$. Komissii po issledovaniyu voprosa o dvizhenii s 1861 g. po 1901 g. blagosostoianiya sel'skogo naseleniya sredne-zemledel'cheskikh gubernii sravnitel'no s drugimi mestnostiami Evropeiskoy Rossii: in 3 parts. St. Peterburg, 1903. Pt. 2. P. 20, 37 (Prilozhenie 1). 
Table 12. Ranking of provinces with predominantly Russian and non-Russian populations by level of welfare in 1901 and by growth rates in 1861-1900

\begin{tabular}{|c|c|c|c|}
\hline $\begin{array}{c}\text { Provinces, populated } \\
\text { predominantly by }\end{array}$ & $\begin{array}{c}\text { Rank by level of } \\
\text { development in } \mathbf{1 9 0 0}\end{array}$ & $\begin{array}{c}\text { Provinces, populated } \\
\text { predominantly by }\end{array}$ & $\begin{array}{c}\text { Rank by growth } \\
\text { rates in 1861-1900 }\end{array}$ \\
\hline Lithuanians & 22.4 & Moldovans & 23.2 \\
\hline Ukrainians & 23.7 & Latvians & 23.5 \\
\hline Russians & 24.9 & Ukrainians & 25.1 \\
\hline Latvians & 26.8 & Russians & 25.2 \\
\hline Belorussians & 27.3 & Lithuanians & 28.8 \\
\hline Moldovans & 28.7 & Belorussians & 29.5 \\
\hline Estonians & 32.4 & Estonians & 34.3 \\
\hline
\end{tabular}

Source: Calculated from the data in Table 11.

In sum, the benefits were mutual. Hence, the disintegration of the integrated economic and political space of the empire in 1917-1918 dealt a severe blow to all the empire's constituents $^{32}$.

The problem of the cost of empire and the empire's unity, however, is of course not confined to economic gains and losses. From the empire's point of view, the issues that played a huge role were the empire's security, its military, economic, and geopolitical power, messianism, cultural and religious predominance, the resolution of internal political problems, the legitimization of the emperor's rule, the prestige of the supreme authority and the state, and other matters. For their part, the borderlands assessed the cost of empire and also took non-material factors into account: the degree of security, the extent of the center's civilizing mission, the danger of assimilation and of the loss of ethnic identity, the desire for ethnocultural autonomy, and others. Appraising the intangible factors is much more difficult and, above all, more problematic, because the perspectives of the center and the peripheral regions differ and it is often impossible to find consensus.

The relationship between the center and the borderlands of the Russian empire was so varied, multifaceted, and dynamic that to express it through a single formula or scenario is impossible. The field of ethnopolitics offers several such schemes to describe the nature of relations between the center and the periphery.

The concept of hegemony, developed initially to explain relations between states in the global system, was subsequently extended to inter-state alliances and multiethnic empires. According to this concept, the imperial system of rule created a special regime that combined the benefits of protection and a single market. The hegemon, or the leading ethnicity, pursuing its own geopolitical and economic interests, its own prestige, and other goals, furnishes the peripheral ethnicities with public goods gratis, or nearly so, in the form of political stability, military defense, investments, markets, and the like ${ }^{33}$.

${ }_{32}$ Bokarev Yu. P. Ekonomicheskie posledstviia...

${ }^{33}$ Abashidze A. H., Il'yashevich $M$. V. Kontseptsiya «gegemonii» v sovremennom mezhdunarodnom prave // Vestnik Diplomaticheskoy akademii MID Rossii «Mezhdunarodnoye pravo». Moscow, 2013. P. 166-79; Pravilova E. A. Finansy imperii... P. 144-146; Kindleberger C. P. Dominance 
An alternative concept, internal colonization, reduces the relations between titular and other ethnicities to domination, subordination, and exploitation. The dominant ethnic group, living in the center, practices discrimination in language, religion, and culture toward ethnic minorities living in the borderlands and promotes ethnic, social, and economic inequality in direct or veiled form. Not infrequently, domination is justified on grounds of racial, ethnic, or cultural superiority; and rule over the periphery becomes established not only through military force but through a complex of discriminatory measures as well. This concept attributes the underdevelopment of internal colonies to their lack of political independence ${ }^{34}$.

The concept of diffusionism shifts the emphasis from relations of dependence to interaction. This concept considers the main substance of the relationship between the center and the periphery to be the process of diffusion, through which stimuli for development penetrate from the center to the periphery, forming conditions for the advancement of the regions and their integration with the center. The spread of new institutions, practices, and cultural models of behavior to the borderlands may be spontaneous, purposeful, or compulsory. This dissemination introduces new, relatively stable social, economic, political, and other elements into the borderlands. Acculturation proceeds under the influence of diffusion, when the dominant ethnic group, entering into prolonged, direct contact with ethnic minorities, alters its original cultural model. Ethnic minorities also exert influence on the dominant ethnicity, however.

These three concepts have many variants, but in essence they reduce to three main scenarios - the center prospers at the expense of the periphery, the periphery prospers at the expense of the center, and the center interacts with the borderlands in the process of diffusion. Analysis of the center's relations with the borderlands in the imperial period shows that at various times and in various regions all three scenarios have been realized, but most often the government followed the concepts of hegemony and diffusion.

The following serve as illustrations indicative of the strategic thinking of imperial leaders. In 1908, Prime Minister Petr A. Stolypin (with the full approval of Nicholas II) explained the government's policy toward the German population in the Baltics to the Baltic GovernorGeneral Aleksandr N. Meller-Zakomel'skii: "The Russian government has never sought to denationalize the nationalities living within the state's borders. The entire course of the empire's historical development demonstrates that, upon the affiliation of lands populated by non-Russian tribes with the state, Russian monarchs, desiring to secure to each nationality its accustomed way of life, typically strove to preserve inviolable the legal relations established in a given locality, while at the same time granting individuals from the affiliated nationalities privileges appropriate to Russian estates (sosloviia). Sometimes, however, it has been necessary to establish certain constraints and restrictions for some parts of the population in the free satisfaction of their civic needs, in the form of protecting the indigenous Russian population and securing the integrity of the state". For example, in the Baltics, too, the aim of the government was the region's internal confluence with Russia, "understanding this merging

and Leadership in the International Economy: Exploitation, Public Goods and Free Riders // International Studies Quarterly. 1981. Vol. 25, No. 2 (June). P. 242-254; Spechler M. Economic Advantages... P. 448-464; Spechler M. Development of the Ukrainian Economy, 1854-1917: The Imperial View // Ukrainian Economic History: Interpretive Essays. Cambridge, 1991. P. 261-276. ${ }^{34}$ Pravilova E. A. Finansy imperii... P. 144-46; Howe S. Empire: A Very Short Introduction. New York, 2002. P. 18-19; Thomas N. Colonialism's Culture: Anthropology, Travel, and Government. Princeton, N.J, 1994. P. 4. 
not as the denationalization of a non-Russian population but as the peaceful commingling of this people with the general course of Russian state life and the possible rapprochement of the local inhabitants with the Russian community while preserving their distinctive religious and tribal characteristics". Appointed officials "ought to be Russian if not by birth then by conviction; the obligation lies on them to protect the interests of Russian statehood in the borderlands, which, obviously, must be placed above any interests of individual nationalities"35.

Governor-General of Turkestan Aleksandr V. Samsonov noted in 1910 in his report on the future structure of the krai: "The ultimate annexation of Bukhara and Khiva is advantageous for Russia, since most likely this will lead to the affiliation of Afghanistan with British possessions, and then obstacles to the joining of Russian railways with Indian ones and the "creation through Russia of a great transit route between the southern countries of Asia and Western Europe" will be eliminated ${ }^{36}$.Minister of War Vladimir A. Sukhomlinov in his report to the tsar on his trip to Turkestan in March-April 1912 noted that the connection of the krai with the empire by means of railways, the introduction of the cultivation of American cotton, and the beginning of a migration movement in the 1880s became "turning points" in its history: "Turkestan has ceased to be a colony in relation to the central part of the empire and enters into an ever closer connection with it with each passing year". This bond rested on Turkestan's role in the general economic life of the state as a cotton producer and as a territory for "the settlement of a Russian peasantry suffering from land shortages". "The widest possible development of cotton cultivation in the krai and the preparation of all areas suitable for settlement under Russian colonization must also serve as the immediate objective toward which the government should necessarily direct all its efforts" ${ }^{37}$. In these statements one clearly sees that economic, geopolitical, and integrative motives defined the empire's policy. Sukhomlinov also acknowledged the colonial element's presence in the early stages of the assimilation of Turkestan, and, one might add, of Siberia as well.

As one can see, the government pursued a policy one can place under the rubrics of internal colonialism, hegemony, and diffusion. The government also had in mind close economic and administrative integration and the mutual benefits flowing from that. But Russian leaders' main concern was to suppress any indications threatening the integrity of the empire. Even the thought of separatism was a nightmare for these leaders, as for all emperors, to say nothing of the dissolution of the empire.

The field of contemporary ethnopolitics proposes several concepts to explain the disintegration of empires. The concept of decolonization, according to which one must place the collapse of an empire in the context of decolonization processes: not the struggle of national movements for independence but the struggle against colonialism destroys an empire ${ }^{38}$.

${ }^{35}$ RGIA. F. 1284 (Departament obshchikh del MVD). Op. 190. D. 84g. L. 38-42. P. A. Stolypin A. N. Meller-Zakomel'skomu (16 March 1908).

${ }^{36}$ RGIA. F. 1276 (Sovet ministrov. 1905-1917 gg.). Op. 2. D. 36. L. 144-147. Svodka naibolee interesnykh vyvodov doklada Samsonova, sostavlennaya N. V. Pleve po porucheniyu P. A. Stolypina (25 October 1910).

${ }^{37}$ RGIA. F. 1276. Op. 2. D. 36. L. 237-244.Vypiska iz vsepoddanneyshego doklada voennogo ministra o poezdke v Turkestanskii krai (March - April 1912).

${ }_{38}$ Sanborn J. Imperial Apocalypse: The Great War and the Destruction of the Russian Empire. New York, 2014. P. 49-72. - In contemporary Russian historiography one can cite the work of 
Structuralist theory exists in two variants. The first emphasizes the interaction between the center and the borderlands: as long as the periphery thinks it is deriving benefit for itself as it supplies the center with resources and receives defense, culture, and technology in return, while the center handles its role of mediator successfully in the borderlands' interactions among themselves, the empire maintains its stability. Exhaustion of the benefits the center provides, attainment by the borderlands of a sufficiently high cultural and economic level, and the equalization of the periphery and the center result in the weakening of the forces preserving the unity of the state. Accordingly, when benefits evaporate or become problematic, collapse occurs ${ }^{39}$.

The second variant of structuralist theory places the center in first place. In large empires borderlands far removed from the center remain outside its reach, lying beyond the range of its influence. As a result, in the remote periphery their own relatively independent centers arise; hence empires appear as the least integrated societies, expressed in the minimal influence of an empire-wide culture and weak inclusion in general imperial law. An empire disintegrates when the Center loses control over the periphery ${ }^{40}$. The incompleteness of the integrative processes in particular in the empire contributes to this outcome ${ }^{41}$.

Constructivist concepts emphasize the artificiality of national communities. Cultural and political elites construct the nation. The intelligentsia of the small ethnic groups assumes the role of an ethnic core, around which the formation of the national idea begins. Their main goal is the awakening of the nation by restoring folk traditions, myths, and an historical past ${ }^{42}$. "Radical constructivists" regard national movements as instruments in the struggle for power. One ought to describe the nation in relational, procedural, and dynamic terms, while nationalism is also possible without the "real" category of the nation. Nationalism and national identity arise not in the course of natural development but as a result of a sudden eruption. The nation becomes a category of nationalists' political practice through an event, not as the product of a lengthy process of development ${ }^{43}$.

The leaders of the Russian empire had not heard of these theories, because in the imperial period these ideas did not yet exist. But officials acted as if they had studied these theories in universities, they worked out their strategy based upon these ideas, and they

V. S. Diakin as an example of this line of thought: Dyakin V.S. Natsional'nyi vopros vo vnutrennei politike tsarizma (XIX - nachalo XX v.). St.-Peterburg, 1998).

${ }^{39}$ Motyl'A . Puti imperii: upadok, krah i vozrozhdenie imperskikh gosudarstv = Imperial Ends: The Decay, Collapse, and Revival of Empires]. Moscow, 2004. P. 143-44; Eisenstadt S. N. Centerperiphery Relations in Soviet Empire // Thinking Theoretically about Soviet Nationalities: History and Comparison in the Study of the USSR . New York, 1992. P. 205-221.

${ }_{40}$ Shils E. Center and Periphery. Essays in Macrosociology. Chicago, 1975; The Fall of Great Powers: Peace, Stability, and Legitimacy. Oslo: Scandinavian University Press; New York, 1994.

${ }^{41}$ Riber A. Sravnivaia kontinental'nye imperii // Rossiiskaia imperiia v sravnitel'noi perspektive. Moscow, 2004. P. 65; Suni R. G. Imperiya kak takovaya: imperskaya Rossiya, «nacional'naya» identichnost' i teorii imperii // Gosudarstvo natsii: imperiya i natsional'noe stroitel'stvo v epokhu Lenina i Stalina. Moscow, 2011. P. 57-59.

${ }^{42}$ Groh M. Konsensusnoe ob'yasnenie formirovaniya natsii // Voprosy filosofii. 2011. No. 1. P. 27-36. - See also: Smith A. The Ethnic Origins of Nations. United Kindom; USA: Oxford, New York, 1987. P. 154.

${ }^{43}$ Brubejker R. Etnichnost' bez grupp. Moscow, 2012. P. 14-21, 60. 
put them to use in their practical activities. The leaders foresaw all the dangers of the disintegration of empire these theories suggest and did everything possible to prevent and preempt such an outcome. The government's administrative resources proved too weak for this, however.

In sum, the analysis conducted in this article concludes that the center's relations with the borderlands in the imperial period at different times and in different regions were enacted in accordance with various strategies. More often than not, however, the government pursued a policy of hegemony and integration. Occasionally, one encounters elements of colonialism in the early stages of the acquisition of the borderlands. Close administrative, legal, and economic integration on the basis of mutual advantages continuously lies at the center of the government's attention. But the main purpose of the supreme authority and its government consisted of preserving the integrity of the empire. For this reason, they were prepared to make any sacrifices on the part of the Russians. In extreme cases, however, they required that other peoples of the empire also sacrifice their own interests for a time.

Информация о статье

Работа выполнена при поддержке Российского научного фонда, грант № 15-18-00119 «Исторический опыт управления этническим разнообразием и этноконфессиональными конфликтами в имперской, советской и постсоветской России: междисциплинарное исследование».

Автор: Миронов, Борис Николаевич - доктор исторических наук, профессор, Санкт-Петербургский государственный университет, Санкт-Петербург, Россия, mironov1942@yandex.ru, OrcID 0000-00018559-0019, ResearcherID F-8909-2015, ScopusID 7004707984, SPIN-код 7919-3929

Название: The cost of Empire' unity in Late Imperial Russia [Цена единства Российской империи]

Резюме: Правительство постоянно беспокоилось о «цене империи», которую понимало как финансовые издержки за удержание какой-либо окраины в составе государства. Министерство финансов вычисляло цену как разницу между государственными расходами на содержание администрации и войск, обустройство границ и городов, проведение железных дорог, а также других затрат от казны, с одной стороны, и бюджетными доходами от всех налогов и прибылей, которые государственное казначейство получало, - с другой. Проблема цены империи и ее единства имеет экономическое измерение, но не сводится к экономическим выгодам и потерям. С точки зрения империи, огромную роль играли вопросы ее безопасности, военной, экономической и геополитической власти, мессианизм, культурное и религиозное преобладание, решение внутренних политических проблем, легитимация власти императора, престиж верховной власти и государства и другие.

Окраины оценивали «цену» империи со своей точки зрения и также учитывали нематериальные факторы. Степень защищенности, мера цивилизаторской миссии Центра, опасность ассимиляции и утраты этнической идентичности, возможность этнокультурной автономии и др. Однако оценить нематериальные факторы намного труднее и главное - проблематичнее, потому что точки зрения Центра и периферийных регионах различались и консенсус найти часто невозможно. Отношения между Центром и окраинами Российской империи были столь разнообразными, многосторонними и динамичными, что подвести их под какую-то одну формулу или один сценарий невозможно. Этнополитология предлагает три схемы для описания природы отношений центра и периферии: концепции гегемонии, внутреннего колониализма и диффузионизма. Чаще всего российское правительство проводило политику гегемонии и интеграции. Элементы колониализма встречались на ранних этапах освоения окраин. Тесная административная, правовая и экономическая интеграции на основе взаимных выгод постоянно находилась в центре его внимания. Но главная цель верховной власти и его правительства состояла в сохранении целостности империи. Ради этого они готовы были идти на любые жертвы со стороны русских. Однако в экстремальных случаях требовали и со стороны других народов империи поступиться своими интересами.

Ключевые слова: Российская империя, концепция гегемонии, концепция внутреннего колониализма, концепция диффузионизма, цена империи, факторы единства империи, политика относительно окраин, центр и окраины, экономическая история, социальная история 


\section{Литература, использованная в статье:}

Anderson B. L., Richardson D. Market Structures and the Profits of the British African Trade in the Late Eighteenth Century: A Rejoinder Rebutted// Journal of Economic History. 1985. Vol. 45. No. 3 (September). P. 705-707.

Anstey R. T. Capitalism and Slavery: a Critique, in Economic History Review. 1968. Vol. 1, No. 2 (August). P. 307-320.

Anstey R. T. The Atlantic Slave Trade and British Abolition, 1760-1810. London: Humanities Press, 1975. $456 \mathrm{p}$.

Beckert S. Empire of Cotton: A Global History. New York: Alfred A. Knopf, 2014. 615 p.

Blackburn R. The Making of New World Slavery: From the Baroque to the Modern, 1492-1800. London; New York: Verso, 2010. 602 p.

Blinkhorn M. Spain: the 'Spanish Problem' and the Imperial Myth // Journal of Contemporary History. 1980. Vol. 15. No. 1 (January). P. 5-25.

Brunschwig H. French Colonialism, 1871-1914. Myths and Realities. London: Pall Mall Press, 1966. 228 p. Clarence-Smith W. G. The Third Portuguese Empire, 1825-1975: A Study in economic imperialism.

Manchester, U. K.; Dover, N. H.: Manchester University Press, 1985. 246 p.

Davis L. E., Huttenback R. A. Mammon and the Pursuit of Empire: The Economics of British Imperialism. Cambridge; N. Y.: Cambridge University Press. 1988. 308 p.

Disparities in Economic Development since the Industrial Revolution / Ed. by. Paul Bairoch, M. LévyLeboyer. London: Macmillan, 1981. 428 p.

Edelstein M. Imperialism: Cost and Benefit, in The Economic History of Britain since 1700 / Ed. by R. Floud, D. McCloskey. $2^{\text {nd }}$ ed. Cambridge: Cambridge University Press, 1994. Vol. 2. P. 197-216.

Eisenstadt S. N. Center-periphery Relations in Soviet Empire// Thinking Theoretically about Soviet Nationalities: History and Comparison in the Study of the USSR / A. J. Motyl' (ed.). New York: Columbia University Press, 1992. P. 205-221.

Eltis D., Engerman S. The Importance of Slavery and Slave Trade to Industrializing Britain // Journal of Economic History. 2000. Vol. 60. No. 1. P. 123-144.

Engerman S. E. The Slave Trade and British Capital Formation in the Eighteenth Century: A Comment on Williams Thesis // Business History Review. 1972. Vol. 46, No. 4 (Winter). P. 430-443.

Good D. F. The Economic Rise of the Habsburg Empire, 1750-1914. Berkeley: University of California Press. 1984. 309 p.

Hopkins A. G. Accounting for the British Empire // Journal of Imperial and Commonwealth History. 1988. Vol. 16. No. 2. P. 234-247. Published online - 1 July 2008. (Access mode: https://doi. org/10.1080/03086538808582759 (last visited - 13 May 2019)).

Hopkins A. G. The Burdens of Empire-Building // African Affairs. 1978. No. 11. P. 108-120.

Howe S. Empire: A Very Short Introduction. New York: Oxford University Press, 2002.

Imperialism and Underdevelopment: A Reader / Ed. by Robert I. Rhodes. New York: Monthly Review Press, 1971. $416 \mathrm{p}$.

Inikori J. E. Africans and the Industrial Revolution in England: A Study in International Trade and Economic Development. New York: Cambridge University Press, 2002. 576 p.

Inikori J. E. Market Structures and the Profits of the British African Trade in the Late Eighteenth Century. A Rejoinder, in Journal of Economic History. 1981. Vol. 41. No. 4. P. 745-776.

Inikori J. E. Slavery and the Rise of Capitalism. Mona, Jamaica: Dept. of History, the University of the West Indies, $1993.33 \mathrm{p}$.

Kesner R. M. Economic Control and Colonial Development: Crown Colony Financial Management in the Age of Joseph Chamberlain. Westport. Conn.: Greenwood Press, 1981. 305 p.

Kindleberger C. P. Dominance and Leadership in the International Economy: Exploitation, Public Goods and Free Riders // International Studies Quarterly. 1981. Vol. 25. No. 2 (June). P. 242-254.

Lundestad G. The Fall of Empires: Peace, Stability and Legitimacy // The Fall of Great Powers: Peace, Stability, and Legitimacy / G. Lundestad (ed.). Oslo: Scandinavian University Press; New York: Oxford University Press, 1994. P. 383-402.

Maddison A. World Population, GDP and Per Capita GDP, 1-2008 AD // Groningen Growth and Development Centre (Access mode: http://www.ggdc.net/Maddison/https://www.nuffield.ox.ac.uk/users/Broadberry/ EuroGDP2.pdf 27 October 2011 File: EuroGDP2 (last visited - 23 August 2017)). 
Matis H. Guidelines of Austrian Economic Policy, 1848-1918 // The Economic Development of Austria since 1870 / Ed. by Herbert Matis. Aldershot. England: Brookfield, Vt., USA: E. Elgar, 1994. 597 p.

Misra M. Lessons of Empire: Britain and India // SAIS Review: A Journal of International Affairs. 2003. Vol. XXIII. No. 2 (Summer-Fall). P. 133-153.

$O$ 'Brien P., Engerman S. Exports and the Growth of the British Economy from the Glorious revolution to the Peace of Amiens, in Slavery and the Rise of the Atlantic System / Ed. by B. Solow. Cambridge: Cambridge University Press, 1991. P. 177-209.

Offer A. Costs and Benefits, Peace and War, in: The Oxford History of the British Empire / Ed. by A. Porter. Oxford: The Oxford University Press, 1999. P. 690-711.

Offer A. The British Empire 1870-1914 - a Waste of Money? // The Economic History Review. 1993. Vol. 45. No. 3. P. 215-238.

Pagden A. The Burdens of Empire: 1539 to the Present. New York, NY : Cambridge University Press, 2015. $288 \mathrm{p}$.

Pamuk S.. A Monetary History of the Ottoman Empire. Cambridge; New York: Cambridge University Press, 2004. $276 \mathrm{p}$.

Penati B. The Cotton Boom and the Land Tax in Russian Turkestan (1880s-1915) // Kritika. 2013. Vol. 14. No.4. P. 741-774.

Porter A. The Balance Sheet of Empire, 1850-1914 // The Historical Journal. 1988. Vol. 31. No. 3 (September). P. 685-699.

Ránki G. On the Economic Development of the Austro-Hungarian Monarchy // Disparities in Economic Development since the Industrial Revolution / Ed. by. P. Bairoch and Maurice Lévy-Leboyer. London: Macmillan, 1981. P. 165-174.

Richardson D. Accounting for Profits in the British Trade in Slaves: Reply to William Darity // Explorations in Economic History. 1989. Vol. 26. No. 4. P. 492-499.

Richardson D. Market Structures and the Profits of the British African Trade in the Late Eighteenth Century: A Comment // Journal of Economic History. 1983. Vol. 43. No. 3 (September). P. 713-721. Published online: 3 March 2009. (Access mode: https://doi.org/10.1017/S0022050700030345 (last visited - 13 May 2019)).

Richardson D. The Slave Trade, Sugar, and British Economic Growth, 1748-1776 // Explorations in Economic History. 1987. Vol. 17. No. 4. P. 739-769.

Sanborn J. Imperial Apocalypse: The Great War and the Destruction of the Russian Empire. New York: Oxford University Press, 2014. 287 p.

Sanborn J. War of Decolonization: The Russian Empire in the Great War // The Empire and Nationalism at War // Eric Lohr, Vera Tolz, Alexander Semyonov, Mark von Hagen (eds). Bloomington, Indiana: Slavica Publishers, 2014. P. 49-72.

Sheridan R. B. Sugar and Slavery: An Economic History of the British West Indies, 1623 1775. Kingston, Jamaica, W.I.: Canoe Press, 1994. 529 p.

ShilsE. A. Center and Periphery. Essays in Macrosociology. Chicago: University of Chicago Press, 1975. $516 \mathrm{p}$.

Sked A. The Decline and Fall of the Habsburg Empire, 1815-1918. London: New York: Longman. 1989. 295 p. Smith A. The Ethnic Origins of Nations. Oxford, UK; New York, NY, USA: B. Blackwell, 1987. 312 p.

Solow B. L. Caribbean Slavery and British Growth: The Eric Williams Hypothesis // Journal of Development Economics. 1985. Vol. 17. No. 1-2. P. 99-115.

Spechler M. C. Development of the Ukrainian Economy, 1854-1917: The Imperial View // Ukrainian Economic History: Interpretive Essays / I. S. Koropeckyj (ed.). Cambridge, Mass.: Distributed by Harvard University Press for the Harvard Ukrainian Research Institute, 1991. P. 261-276.

Spechler M. C. The Economic Advantages of Being Peripheral: Subordinated Nations in Multinational Empires // Eastern European Politics and Societies. 1989. Vol. 3. No. 3 (Fall). P. 448-464.

Thinking Theoretically about Soviet Nationalities: History and Comparison in the Study of the USSR / A. J. Motyl' (ed.). New York, 1992. P. 205-221.

Thomas N. Colonialism's Culture: Anthropology, Travel, and Government. Princeton, N.J.: Princeton University Press, 1994. 238 p.

Valge J. Lahtirakendamine: Eesti Vabariigi majanduse stabiliseerimine 1918-1924. Tallinn: Rahvusarhiiv, 2003. $440 \mathrm{lk}$. 
Williams E. E. Capitalism and Slavery. Kingston; Miami: Ian Randle Publishers, 2005. 285 p.

Williams E. E. The Economic Aspect of the Abolition of the West Indian Slave Trade and Slavery. Lanham: Rowman\&Littlefield, 2014. 253 p.

Абашидзе A. X.; Ильяшевич М. В. Концепция «гегемонии» в современном международном праве // Вестник Дипломатической академии МИД России «Международное право». Москва: Дипломатическая академия МИД России, 2013. С. 166-179.

Белоглазов А. В. Федерализм в «тюрьме народов»: Великое княжество Финляндское // Федерализм: проблемы формирования: материалы постоянно действующего семинара / Под ред. Ю. Р. Хайруллиной, А. Г. Большакова. Казань: Издательство Казанского государственного технологического университета, 1994. С. 41-47.

Бобович И. М. Русско-финляндские экономические отношения накануне Великой Октябрьской социалистической революции: (Эпоха империализма). Ленинград: Издательство Ленинградского университета, 1968. 192 с.

Бокарев Ю. П. Экономические последствия распада российской империи в результате первой мировой войны. Екатеринбург; Москва: Издательство УМЦ УПИ, 2009. 87 с.

Брубейкер Р. Этничность без групп. Москва: Изд. дом Высшей школы экономики, 2012. 408 с.

Грох М. Консенсусное объяснение формирования наций // Вопросы философии. 2011. № 1. С. 27-36. Дякин В. С. Национальный вопрос во внутренней политике царизма (XIX - начало XX в.). СанктПетербург: ЛИСС, 1998. 1039 с.

КаппелерA. Россия - многонациональная империя. Москва: Прогресс-Традиция, 2000. 342 с.

Корнилов Г. Д. Русско-финляндские таможенные отношения в конце XIX - начале XX в. Ленинград: Наука, 1971. 219 с.

Mотыль $A$. Пути империй: упадок, крах и возрождение имперских государств = Imperial Ends: The Decay, Collapse, and Revival of Empires. Москва: Московская школа политических исследований, 2004. $241 \mathrm{c}$.

Национальная политика в императорской России: в 2 т. Т. 1: Цивилизованные окраины (Финляндия, Польша, Прибалтика, Бессарабия, Украина, Закавказье, Средняя Азия) / Ю. И. Семенов (сост., ред.). Москва: Старый сад, 1997. 413 с.

Панин Е.Н. Особенности опыта исторического развития Латвии (1917-1940 гг.): историография и источниковая база проблемы: дис. ... канд. ист. наук. Москва, 2014. 209 с.

Правилова E. А. Финансы империи: Деньги и власть в политике России на национальных окраинах, 1801-1917. Москва: Новое издательство, 2006. 453, [2] с.

Прибалтика и Средняя Азия в составе российской империи и СССР: мифы современных учебников постсоветских стран и реальность социально-экономических подсчётов / А. А. Данилов, А. В. Филиппов (ред.). Москва: Центр общественных технологий, 2009. 199 с.

Расила В. История Финляндии. Петрозаводск: Издательство Петрозаводского государственного университета, 1996. 294 с.

Рибер А. Сравнивая континентальные империи // Российская империя в сравнительной перспективе / А. И. Миллер (ред.). Москва: Новое издательство, 2004. С. 33-71.

Суни Р. Г. Империя как таковая: имперская Россия, «национальная» идентичность и теории империи // Государство наций: империя и национальное строительство в эпоху Ленина и Сталина / Р. Г. Суни, Т. Мартин (ред). Москва: РОССПЭН, 2011. С. 7-20.

Шилз Э. Общество и общества: макросоциологический подход // Американская социология: перспективы, проблемы, методы / Под ред. Г. В. Осипова. Москва: Прогресс, 1972. С. 341-359.

Information about the article:

This research was supported by Russian Science Foundation, grant No. 15-18-00119 "The History of Managing Ethnic Diversity and Ethno-confessional conflicts in Imperial, Soviet, and Post-Soviet Russia: An Interdisciplinary Study".

Author: Mironov, Boris Nikolaevich - Dr. Sc. of Histore, Professor, Saint-Petersburg State University, Saint Petersburg, Russia; mironov1942@yandex.ru, OrcID 0000-0001-8559-0019, ResearcherID F-8909-2015, ScopusID 7004707984, SPIN-cod 7919-3929

Title: The cost of Empire' unity in Late Imperial Russia 
Abstract: The government constantly fretted over the "cost of empire", which it understood as the expense of possessing any borderlands as part of the state. The Ministry of Finance calculated the cost as the difference between state outlays for the maintenance of its administration and armed forces, the construction of borders and towns, and the installation of railways, as well as other expenses from the treasury, on the one hand, and budget revenue from all taxes and income the treasury received, on the other.The problem of the cost of empire and the empire's unity, however, is not confined to economic gains and losses. From the empire's point of view, the issues that played a huge role were the empire's security, its military, economic, and geopolitical power, messianism, cultural and religious predominance, the resolution of internal political problems, the legitimization of the emperor's rule, the prestige of the supreme authority and the state, and other matters. For their part, the borderlands assessed the cost of empire and also took non-material factors into account: the degree of security, the extent of the center's civilizing mission, the danger of assimilation and of the loss of ethnic identity, the desire for ethno-cultural autonomy, and others. Appraising the intangible factors is much more difficult and, above all, more problematic, because the perspectives of the center and the peripheral regions differ and it is often impossible to find consensus. The relationship between the center and the borderlands of the Russian empire was so varied, multifaceted, and dynamic that to express it through a single formula or scenario is impossible. The field of ethnopolitics offers three several such schemes to describe the nature of relations between the center and the periphery: the concept of hegemony, of internal colonization, and of diffusionism. Analysis of the center's relations with the borderlands in the imperial period shows that at various times and in various regions all three scenarios have been realized, but most often the government followed the concepts of hegemony and diffusion. Occasionally, one encounters elements of colonialism in the early stages of the acquisition of the borderlands. Close administrative, legal, and economic integration on the basis of mutual advantages continuously lies at the center of the government's attention. But the main purpose of the supreme authority and its government consisted of preserving the integrity of the empire. For this reason, they were prepared to make any sacrifices on the part of the Russians. In extreme cases, however, they required that other peoples of the empire also sacrifice their own interests for a time.

Keywords: the Russian empire, the cost of empire, the concept of hegemony, the concept of internal colonization, the concept of diffusionism, the factors of unity of the Empire, the policy regarding margins, economic history, social history

\section{References:}

Abashidze, Aslan Khuseinovich; Ilyashevich, Marianna Viktorovna. Kontseptsiya "gegemonii" v sovremennom mezhdunarodnom prave, in Vestnik Diplomaticheskoy akademii MID Rossii «Mezhdunarodnoye pravo». Moscow: Diplomaticheskaya akademiya MID Rossii Press, 2013. Pp. 166-179. (in Russian).

Anderson, B. L.; Richardson, David. Market Structures and the Profits of the British African Trade in the Late Eighteenth Century: A Rejoinder Rebutted, in Journal of Economic History. 1985. Vol. 45. No. 3 (September). Pp. 705-707.

Anstey, Roger T. Capitalism and Slavery: a Critique, in Economic History Review. 1968. Vol. 1. No. 2 (August). Pp. 307-320.

Anstey, Roger T. The Atlantic Slave Trade and British Abolition, 1760-1810. London: Humanities Press, 1975. $456 \mathrm{p}$.

Beckert, Sven. Empire of Cotton: A Global History. New York: Alfred A. Knopf Publ., 2014. 615 p.

Beloglazov, Al'bert Vladislavovich. Federalizm v “tyur'me narodov": Velikoe knyazhestvo Finliandskoye, in Federalizm: problemy formirovaniya: materialy postoyannodeystvuyushchego seminara. Eds Iu. R. Khairullina, A. G. Bol'shakov. Kazan': Kazan State Technological University Press, 1994. Pp. 41-47. (in Russian). Blackburn, Robin. The Making of New World Slavery: From the Baroque to the Modern, 1492-1800. London; New York: Verso Publ., 2010. 602 p.

Blinkhorn, Martin. Spain: the 'Spanish Problem' and the Imperial Myth, in Journal of Contemporary History. 1980. Vol. 15. No. 1 (January). Pp. 5-25.

Bobovich, Irina Mikhailovna. Russko-finlyandskiye ekonomicheskiye otnosheniya na kanune Velikoy Oktyabr'skoy sotsialisticheskoy revolyutsii: (Epokha imperializma). Leningrad: Leningrad State University Press, 1968. 192 p. (in Russian).

Bokarev, Uriy Pavlovich. Ekonomicheskiye posledstviya raspada rossiyskoy imperii v rezul'tate Pervoy mirovoy voyny. Ekaterinburg; Moscow: UMTs UPI Publ., 2009. 87 p. (in Russian). 
Brubejker, Rodzhers. Etnichnost'bez grupp. Moscow: The Higher School of Economics Publishing House, 2012. 408 p. (in Russian).

Brunschwig, Henri. French Colonialism, 1871-1914. Myths and Realities. London: Pall Mall Press, 1966. $228 \mathrm{p}$.

Clarence-Smith, W. G. The Third Portuguese Empire, 1825-1975: A Study in economic imperialism. Manchester, U.K.; Dover, N.H.: Manchester University Press, 1985. 246 p.

Davis, Lance E.; Huttenback, Robert A. Mammon and the Pursuit of Empire: The Economics of British Imperialism. Cambridge; New York: Cambridge University Press. 1988. 308 p.

Diakin, Valentin Semenovich. Natsional'niy vopros vo vnutrenney politike tsarizma (XIX - nachalo XX v.). St. Peterburg: LISS Publ., 1998. 1039 p. (in Russian).

Disparities in Economic Development since the Industrial Revolution. Ed. by. Paul Bairoch, M. Lévy-Leboyer. London: Macmillan Publ., 1981. 428 p.

Edelstein, Michael. Imperialism: Cost and Benefit, in The Economic History of Britain since 1700. Ed. by Floud, Roderick and McCloskey, Donald. $2^{\text {nd }}$ ed. Cambridge: Cambridge University Press, 1994. Vol. 2. Pp. 197-216.

Eisenstadt, Shmuel Noah. Center-periphery Relations in Soviet Empire, in Thinking Theoretically about Soviet Nationalities: History and Comparison in the Study of the USSR. Ed. by A. J. Motyl'. New York: Columbia University Press, 1992. Pp. 205-221.

Eltis, David and Engerman, Stanley. The Importance of Slavery and Slave Trade to Industrializing Britain, in Journal of Economic History. 2000. Vol. 60. No. 1. Pp. 123-144.

Engerman, Stanley E. The Slave Trade and British Capital Formation in the Eighteenth Century: A Comment on Williams Thesis, in Business History Review. 1972. Vol. 46. No. 4 (Winter). Pp. 430-443.

Good, David F. The Economic Rise of the Habsburg Empire, 1750-1914. Berkeley: University of California Press. 1984. 309 p.

Grokh, Miroslav. Konsensusnoe ob'yasneniye formirovaniya natsii, in Voprosy filosofii. 2011. No. 1. S. 27-36. (in Russian).

Hopkins, Antony G. Accounting for the British Empire, in Journal of Imperial and Commonwealth History. 1988. Vol. 16. No. 2. Pp. 234-247.

Hopkins, Antony G. The Burdens of Empire-Building, in African Affairs. 1978. No. 11. Pp. 108-120.

Howe, Stephen. Empire: A Very Short Introduction. New York: Oxford University Press, 2002. 255 p.

Imperialism and Underdevelopment: A Reader. Ed. by Robert I. Rhodes. New York: Monthly Review Press, 1971. $416 \mathrm{p}$.

Inikori, Joseph E. Africans and the Industrial Revolution in England: A Study in International Trade and Economic Development. New York: Cambridge University Press, 2002. 576 p.

Inikori, Joseph E. Market Structures and the Profits of the British African Trade in the Late Eighteenth Century. A Rejoinder, in Journal of Economic History. 1981. Vol. 41. No. 4. Pp. 745-776.

Inikori, Joseph E. Slavery and the Rise of Capitalism. Mona, Jamaica: Dept. of History, the University of the West Indies Press, 1993. 33 p.

Kappeler, Andreas. Rossiya - mnogonatsional 'naya imperiya. Moscow: Progress-Traditsya Publ., 2000. 342 s. (in Russian).

Kesner, Richard M. Economic Control and Colonial Development: Crown Colony Financial Management in the Age of Joseph Chamberlain. Westport. Conn.: Greenwood Press, 1981. 305 p.

Kindleberger, Charles Poor. Dominance and Leadership in the International Economy: Exploitation, Public Goods and Free Riders, in International Studies Quarterly. 1981. Vol. 25. No. 2 (June). Pp. 242-254.

Kornilov, Genrikh Dmitrievich. Russko-finlyandskiye tamozhennye otnosheniya v kontse XIX-nachale XXv. Leningrad: Nauka Publ., 1971. 219 p. (in Russian).

Lundestad, Geir. The Fall of Empires: Peace, Stability and Legitimacy, in The Fall of Great Powers: Peace, Stability, and Legitimacy. Ed by Geir Lundestad. Oslo: Scandinavian University Press; New York: Oxford University Press, 1994. Pp. 383-402.

Maddison, Angus. World Population, GDP and Per Capita GDP, 1-2008 AD, in Groningen Growth and Development Centre (Access mode: http://www.ggdc.net/Maddison/https://www.nuffield.ox.ac.uk/users/ Broadberry/EuroGDP2.pdf 27 October 2011 File: EuroGDP2 (last visited - 23 August 2017).

Matis, Herbert. Guidelines of Austrian Economic Policy, 1848-1918, in The Economic Development of Austria since 1870. Ed. by Herbert Matis. Aldershot. England: Brookfield, Vt., USA: E. Elgar Publ., 1994. 597 p. 
Misra, Maria. Lessons of Empire: Britain and India, in SAIS Review: A Journal of International Affairs. 2003. Vol. XXIII. No. 2 (Summer-Fall). Pp. 133-153.

Motyl', Aleksandr. Imperial Ends: The Decay, Collapse, and Revival of Empires. Moscow: Moskovskaya shkola politicheskikh issledovaniy Press, 2004. 241 p. (in Russian).

Natsional'naya politika $v$ imperatorskoy Rossii: in 2 vols. Vol. 1: Tsivilizovannye okrainy (Finliandiya, Pol'sha, Pribaltika, Bessarabiya, Ukraina, Zakavkazye, Srednyaya Aziya). Ed. by Iu. I. Semenov. Moscow: Staryi sad Publ., 1997. 413 p. (in Russian).

O'Brien, Patrick and Engerman, Stanley. Exports and the Growth of the British Economy from the Glorious revolution to the Peace of Amiens, in Slavery and the Rise of the Atlantic System. Ed. by Barbara Solow. Cambridge: Cambridge University Press, 1991. Pp. 177-209.

Offer, Avner. Costs and Benefits, Peace and War, in The Oxford History of the British Empire. Ed. by A. Porter. Oxford: The Oxford University Press, 1999. Pp. 690-711.

Offer, Avner. The British Empire 1870-1914 - a Waste of Money?, in The Economic History Review. 1993. Vol. 45, No. 3. Pp. 215-238.

Pagden, Anthony. The Burdens of Empire: 1539 to the Present. New York: Cambridge University Press, 2015. $288 \mathrm{p}$.

Pamuk, Şevket. A Monetary History of the Ottoman Empire. Cambridge; New York: Cambridge University Press, 2004. 276 p.

Panin, Evgeniy Nikolaevich. Osobennosti opyta istoricheskogo razvitiya Latvii (1917-1940 gg.): istoriografiya $\mathrm{i}$ istochnikovaya baza problemy. Dis. ... kand. ist. nauk. Moscow: Russian State University for the Humanities Press, 2014. 209 p. (in Russian).

Penati, Beatrice. The Cotton Boom and the Land Tax in Russian Turkestan (1880s-1915), in Kritika. 2013. Vol. 14. No. 4. Pp. 741-774.

Porter, Andrew. The Balance Sheet of Empire, 1850-1914, in The Historical Journal. 1988. Vol. 31. No. 3 (September). Pp. 685-699.

Pravilova, Ekaterina Anatolyevna. Finansy imperii: Den'gi i vlast' v politike Rossii na natsional'nykh okrainakh, 1801-1917. Moscow: Novoe izdatel'stvo Publ., 2006. 453, [2] p. (in Russian).

Pribaltika i Sredniaya Aziya v sostave rossiyskoy imperii i SSSR: mify sovremennykh uchebnikov postsovetskikh stran i real'nost' sotsial'no-ekonomicheskikh podschetov. Eds. A. A. Danilov, A. V. Filippov. Moscow: Tsentr obshchestvennykh tekhnologiy Press, 2009. 199 p. (in Russian).

Ránki, György. On the Economic Development of the Austro-Hungarian Monarchy, in Disparities in Economic Development since the Industrial Revolution. Ed. by. Paul Bairoch and Maurice Lévy-Leboyer. London: Macmillan Publ., 1981. Pp. 165-174.

Rasila, Vilyo. Istoriya Finlyandii. Petrozavodsk: Petrozavodsk State University Press, 1996. 294 p. (in Russian). Riber, Al'fred. Sravnivaya kontinental'nye imperii, in Rossiyskaya imperiya v sravnitel'noy perspektive. Ed. by A. I. Miller. Moscow: Novoe izdatel'stvo Publ., 2004. Pp. 33-71. (in Russian).

Richardson, David. Accounting for Profits in the British Trade in Slaves: Reply to William Darity, in Explorations in Economic History. 1989. Vol. 26. No. 4. Pp. 492-499.

Richardson, David. Market Structures and the Profits of the British African Trade in the Late Eighteenth Century: A Comment, in Journal of Economic History. 1983. Vol. 43. No. 3 (September). Pp. 713-721.

Richardson, David. The Slave Trade, Sugar, and British Economic Growth, 1748-1776, in Explorations in Economic History. 1987. Vol. 17. No. 4. Pp. 739-769.

Sanborn, Joshua. Imperial Apocalypse: The Great War and the Destruction of the Russian Empire. New York: Oxford University Press, 2014. 287 p.

Sanborn, Joshua. War of Decolonization: The Russian Empire in the Great War, in The Empire and Nationalism at War. Eds Eric Lohr, Vera Tolz, Alexander Semyonov, Mark von Hagen. Bloomington, Indiana: Slavica Publishers, 2014. Pp. 49-72.

Sheridan, Richard B. Sugar and Slavery: An Economic History of the British West Indies, 1623-1775. Kingston, Jamaica, W. I.: Canoe Press, 1994. 529 p.

Shils, Edward Albert. Center and Periphery: Essays in Macrosociology. Chicago: University of Chicago Press, 1975. $516 \mathrm{p}$.

Shilz, Eduard. Obshchestvo i obshchestva: makrosotsiologicheskiy podkhod, in Amerikanskaya sotsiologiya: perspektivy, problemy, metody. Ed. by G. V. Osipov. Moscow: Progress Publ., 1972. Pp. 341-359. (in Russian). 
Sked, Alan. The Decline and Fall of the Habsburg Empire, 1815-1918. London: New York: Longman Publ., 1989. 295 p.

Smith, Anthony. The Ethnic Origins of Nations. Oxford, UK; New York, NY, USA: B. Blackwell Publ., 1987. $312 \mathrm{p}$.

Solow, Barbara L. Caribbean Slavery and British Growth: The Eric Williams Hypothesis, in Journal of Development Economics. 1985. Vol. 17. No. 1-2. Pp. 99-115.

Spechler, Martin C. Development of the Ukrainian Economy, 1854-1917: The Imperial View, in Ukrainian Economic History: Interpretive Essays. Ed. by I. S. Koropeckyj. Cambridge, Mass.: Distributed by Harvard University Press for the Harvard Ukrainian Research Institute, 1991. Pp. 261-276.

Spechler, Martin C. The Economic Advantages of Being Peripheral: Subordinate Nations in Multinational Empires, in Eastern European Politics and Societies. 1989. Vol. 3. No. 3. Pp. 448-464.

Suni, Ronald Grigor. Imperiya kak takovaya: Imperskaya Rossiya, «natsional'naya» identichnost' i teorii imperii, in Gosudarstvo natsii: imperiya i natsional'noye stroitel'stvo v epokhu Lenina i Stalina. Eds R. G. Suni, T. Martin. Moscow: ROSSPEN Press, 2011. Pp. 7-20. (in Russian).

Thinking Theoretically about Soviet Nationalities: History and Comparison in the Study of the USSR. Ed. by A. J. Motyl'. New York, 1992. Pp. 205-221.

Thomas, Nicholas. Colonialism's Culture: Anthropology, Travel, and Government. Princeton, N. J.: Princeton University Press, 1994. 238 p.

Valge, Jaak. Lahtirakendamine: Eesti Vabariigi majanduse stabiliseerimine 1918-1924. Tallinn: Rahvusarhiiv Publ., 2003. 440 p. (in Estonian).

Williams, Eric E. Capitalism and Slavery. Kingston; Miami: Ian Randle Publishers, 2005. 285 p.

Williams, Eric E. The Economic Aspect of the Abolition of the West Indian Slave Trade and Slavery. Lanham: Rowman and Littlefield Publ., 2014. 253 p. 